\title{
O QUE É FAZER-FARINHA NA COMUNIDADE QUILOMBOLA UXIZAL DE MOCAJUBA, BAIXO TOCANTINS, PARÁ?
}

\author{
Amalia Gabriela Rocha Aguiar ${ }^{1}$ \\ Rumi Regina Kubo ${ }^{2}$
}

A presente narrativa remete a uma ação de pesquisa e extensão, realizada durante o ano de $2014^{3}$, na comunidade quilombola Uxizal, localizada no município de Mocajuba, Estado do Pará, que tinha como foco central o estudo do sistema de cultivo e beneficiamento da mandioca para a produção de farinha. A farinha de Uxizal desfruta do reconhecimento dos consumidores em todo o município pela sua qualidade, sendo fator de reafirmação de identidade, uma vez que é referida como "a farinha dos quilombolas". O título de terras em regime coletivo foi concedido a Associação dos Remanescentes de Quilombos do $2^{\circ}$ Distrito de Mocajuba, em 2008, a partir do reconhecimento como área remanescente de quilombo pelo Instituto de Terras do Pará (ITERPA), órgão executor da política agrária do Estado. Uxizal, com 52 famílias, é uma das sete comunidades quilombolas que compõe esta Associação. Na referida pesquisa, centrada nos aspectos técnicos e agronômicos, foram salientadas as transformações ocorridas ao longo do tempo nas práticas destas famílias da comunidade quilombola ${ }^{4}$. Como forma de registro foram efetuadas capturas na forma de fotografias de todo o processo, com a anuência dos interlocutores, que foram Dona Ediléia junto com seu marido e a Dona Deuza. Passados cinco anos, essas imagens foram revisitadas pela responsável pela captura destas e neste ensaio, procurou-se constituir uma narrativa resgatando os sentidos das reflexões agronômicas e sua expressão nas imagens. Neste esforço reflexivo a partir das imagens, remetemos a evocação dos sentidos contidos no processo de produção da farinha, em que estão envolvidas questões econômicas, pois se constitui, junto com a pimenta, a principal fonte de recursos monetários desta

\footnotetext{
${ }^{1}$ Universidade Federal do Rio Grande do Sul, Brasil. Email: agr.aguiar@gmail.com ORCID id : https://orcid.org/0000-0002-3175-2016

${ }^{2}$ Universidade Federal do Rio Grande do Sul, Brasil. Email: rumikubo2002@gmail.com ORCID id: https://orcid.org/0000-0002-2336-1402

${ }^{3}$ Com o apoio do PROEXT/MEC realizado no âmbito do Grupo Diversidade Socioagroambiental na Amazônia (GEDAF) da Universidade Federal do Para (UFPA).

${ }^{4}$ AGUIAR, Amália G. R.; QUARESMA, Camila R., SIMÕES, Aquiles V. Interface de saberes e inovação no sistema técnico de cultivo da mandioca na comunidade Uxizal, Mocajuba, estado do Pará. Amazônia: Ciência e Desenvolvimento, v. 12, n. 22, p. 21-32, 2016.
}

Iluminuras, Porto Alegre, v. 21, n. 54, p. 871-889, setembro, 2020. 
comunidade $^{5}$, mas também buscamos cotejar outros elementos como a imersão na paisagem $^{6} \mathrm{e}$ o acionamento de diferentes esferas e aspectos relacionadas à sociabilidade do grupo (cultivo e processamento da mandioca, práticas e saberes associados, passagem de conhecimento, o ritual alimentar) e que não nos deixa esquecer da noção de totalidade da conexão entre corpo e técnica, proposta por Marcel Mauss ${ }^{7}$ e que aqui designamos como "fazer-farinha". Há nessa configuração que remete a um fato social total não somente a interação entre os seres humanos, homens e mulheres de diferentes faixas etárias, mas entre humanos e não-humanos (plantas, artefatos, minerais), cimentados por uma inevitável evocação (Stephen Tyler ${ }^{8}$ ) ao espírito da reciprocidade ${ }^{9}$. Cabe também ressaltar que os sentidos desta totalidade remetem a um saber-fazer ${ }^{10}$, ancorado na tradição, mas que se trata de uma tradição que adquire novos sentidos ao ser lido (e visto) por toda uma comunidade moderna urbano-industrial. Este é o convite a que se propõe a presente narrativa: o que tais imagens provocam em nossos olhares moderno-urbano-industrial-ambientalizados?

\footnotetext{
${ }^{5}$ Conforme dados da Embrapa (2017) o Estado do Pará é o maior produtor de mandioca com uma área cultivada de 295.137 hectares (20,97\% da área plantada nacional) e uma produção de 4.234 .597 toneladas sendo a quase totalidade da produção destinada à produção de farinha de mesa. https://www.embrapa.br/congresso-de-mandioca-2018/mandioca-em-numeros

"INGOLD, Tim, "Temporality of the landscape" [1933]. In: T. Ingold, The Perception of the Environment. Essays in livelihood, dwelling and skill, Londres, Routledge, 2000 e INGOLD, Tim. Estar vivo: ensaios sobre movimento, conhecimento e descrição. São Paulo: Vozes, 2015.

${ }^{7}$ MAUSS, Marcel. Sociologia e Antropologia. São Paulo: EPU/Edusp, 2017 [1936].

${ }^{8}$ TYLER, Stephen. Escrita pos-moderna: do documento do oculto ao documento oculto. In: CLIFFORD, James, MARCUS, George. A escrita da cultura: poética e política da etnografia. Rio de Janeiro: Papéis Selvagens/EdUFRJ, 2016. pp. 183-206

${ }^{9}$ MAUSS, Marcel. Sociologia e Antropologia. São Paulo: EPU/Edusp, 2017 [1936].; LÉVI-STRAUSS, Claude. Introdução à obra de Marcel Mauss. In: Ensaio sobre a dádiva. Lisboa, Edições 70, s/d; SABOURIN, Eric. Sociedades e organizações camponesas: uma leitura através da reciprocidade. Porto Alegre: Editora da UFRGS, 2011.

${ }^{10}$ WOORTMANN, Ellen F., WOORTMANN, Klaas. O trabalho da terra. Brasília: Editora UnB, 1997.
} 


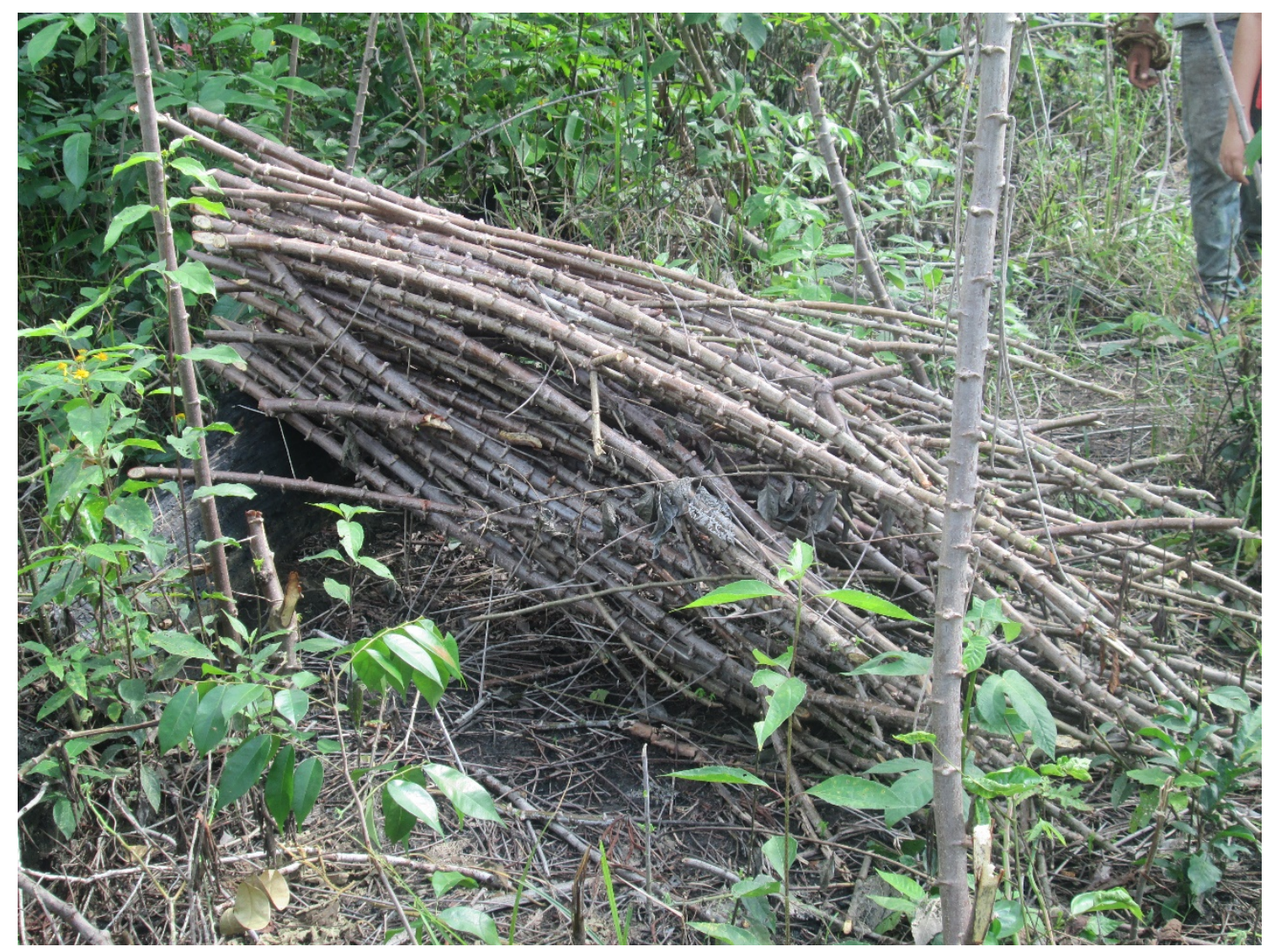

O fazer-farinha é também... escolha...

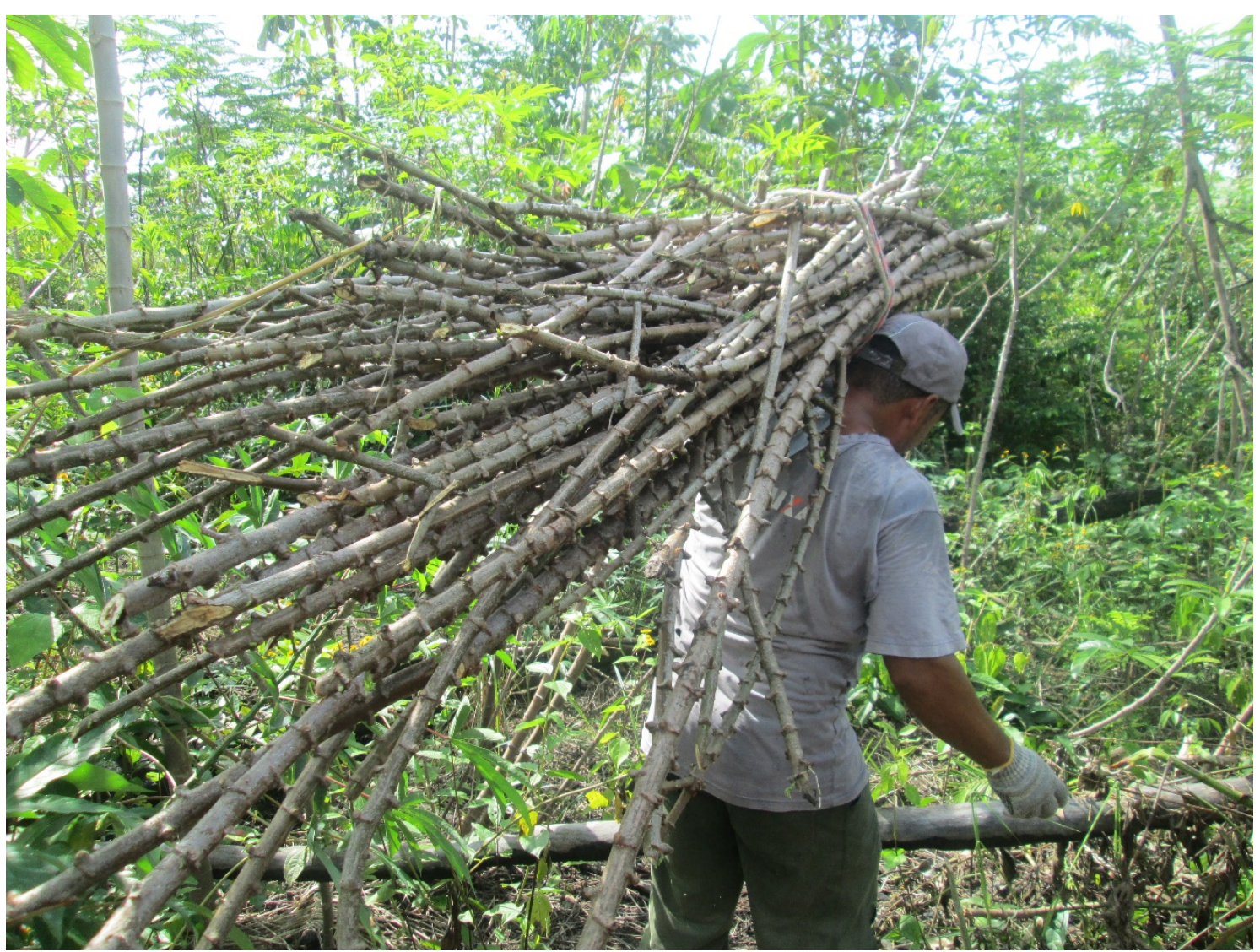

Iluminuras, Porto Alegre, v. 21, n. 54, p. 871-889, setembro, 2020. 
Escolha das variedades...

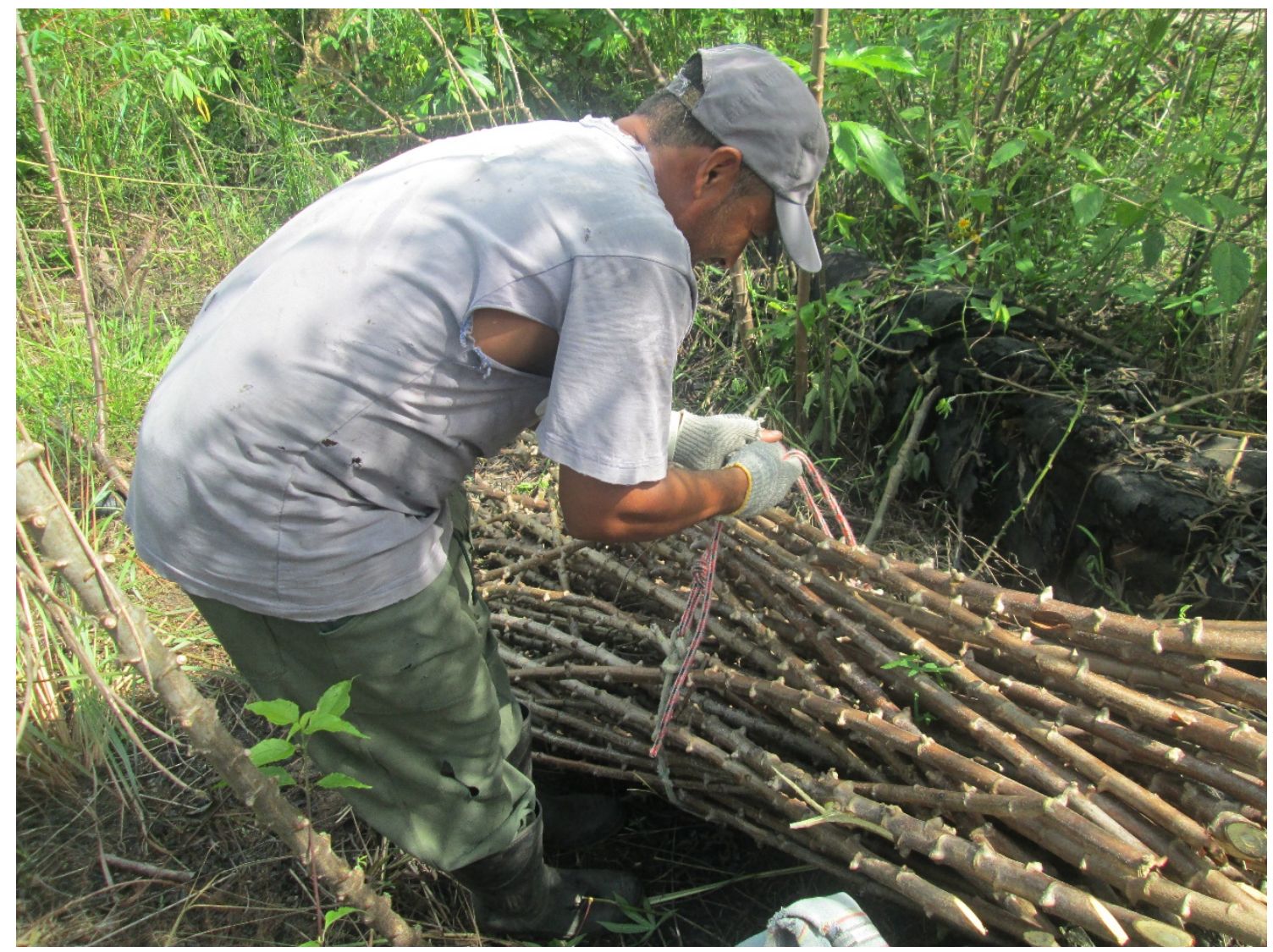

Escolha dos feixes de maniva...

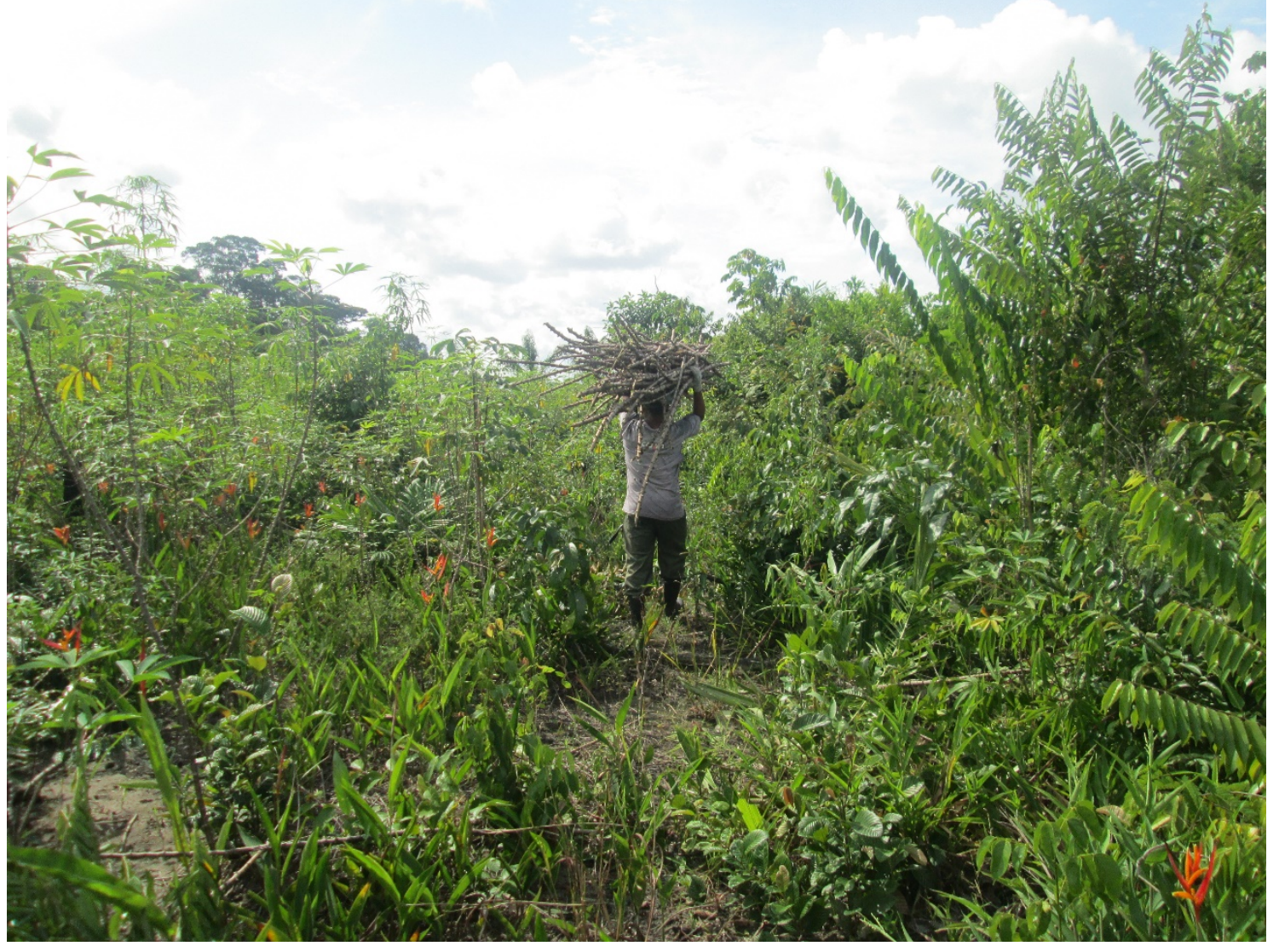

Iluminuras, Porto Alegre, v. 21, n. 54, p. 871-889, setembro, 2020. 


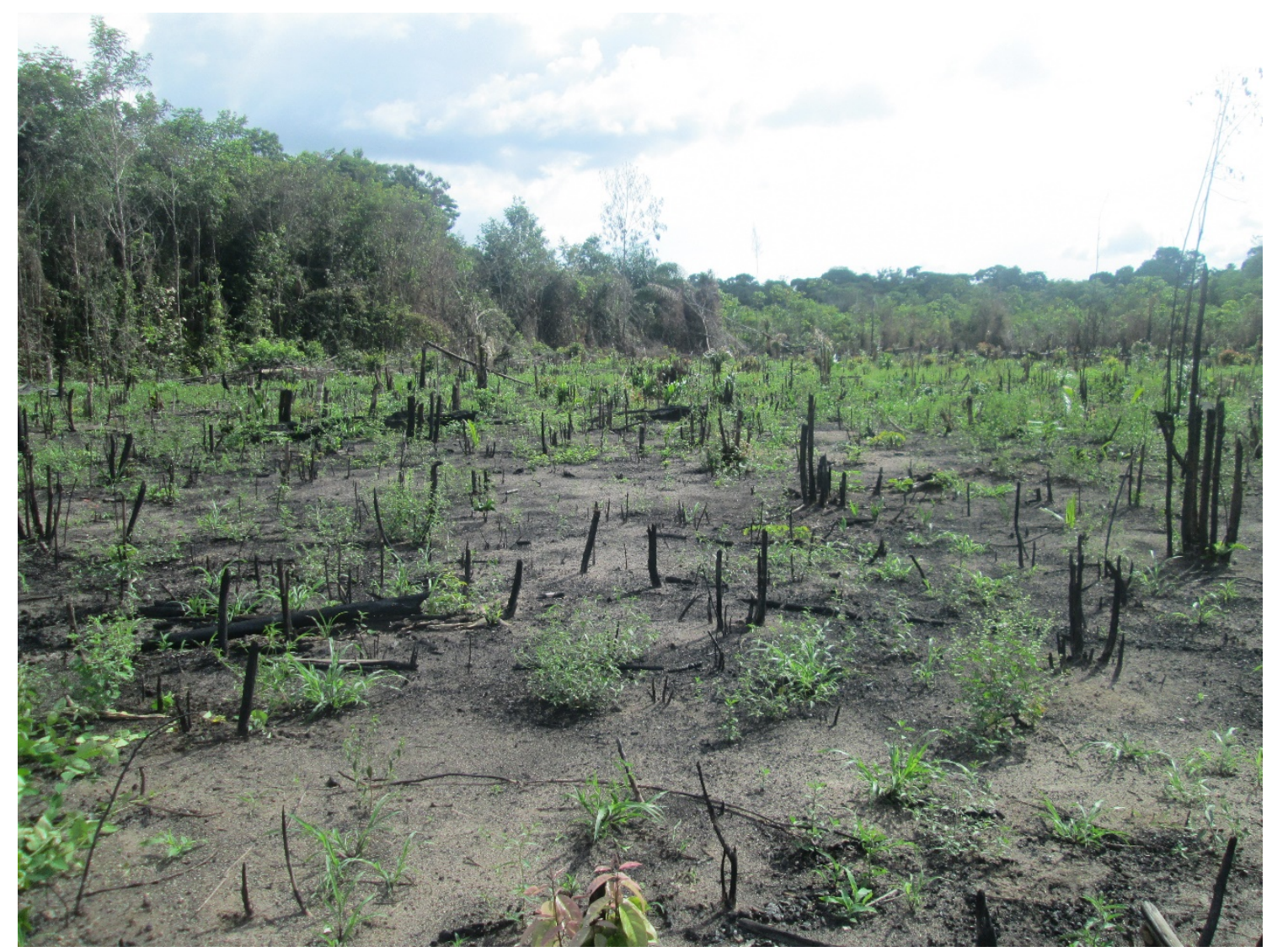

Escolha das áreas...

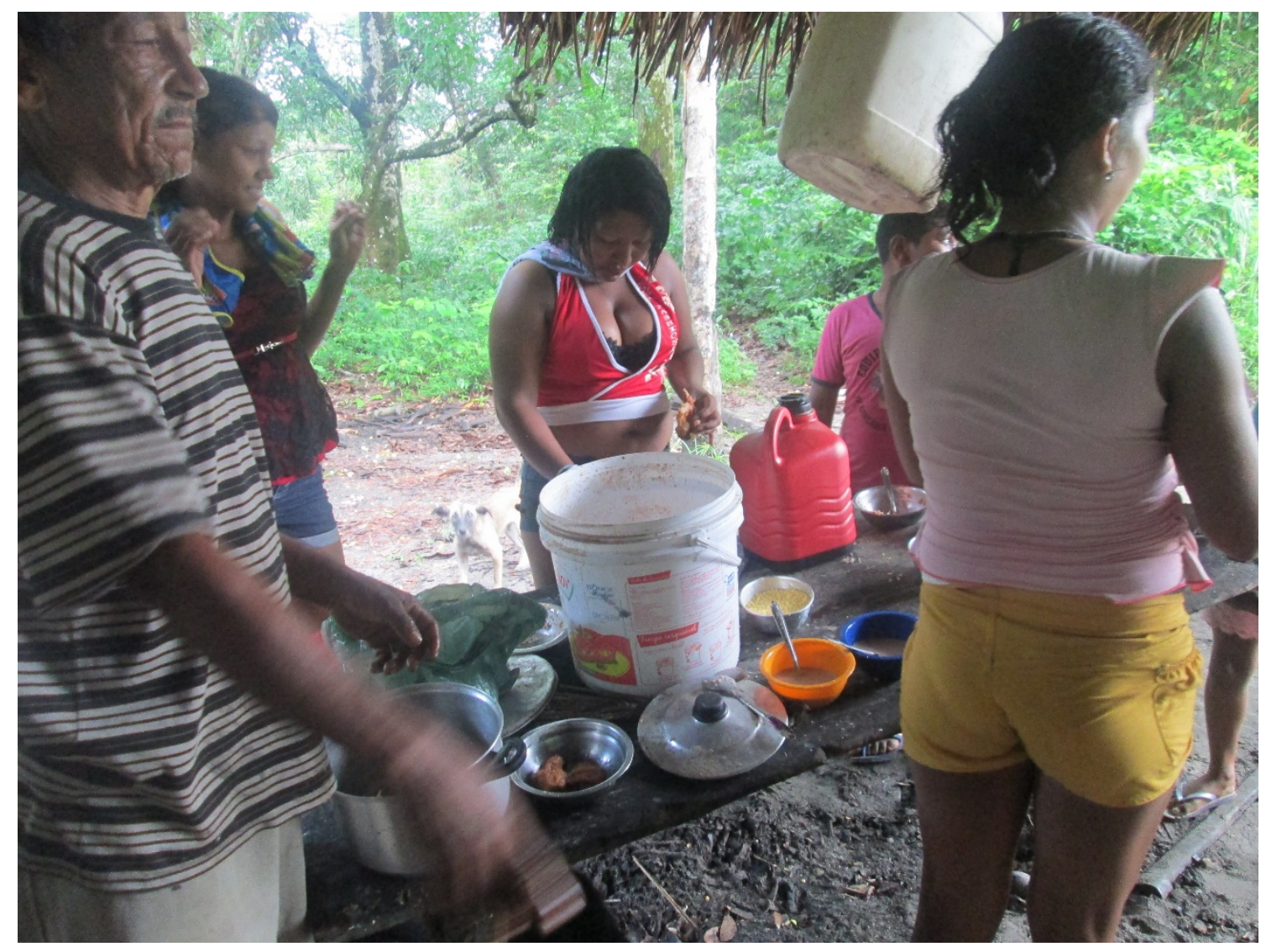

Iluminuras, Porto Alegre, v. 21, n. 54, p. 871-889, setembro, 2020. 


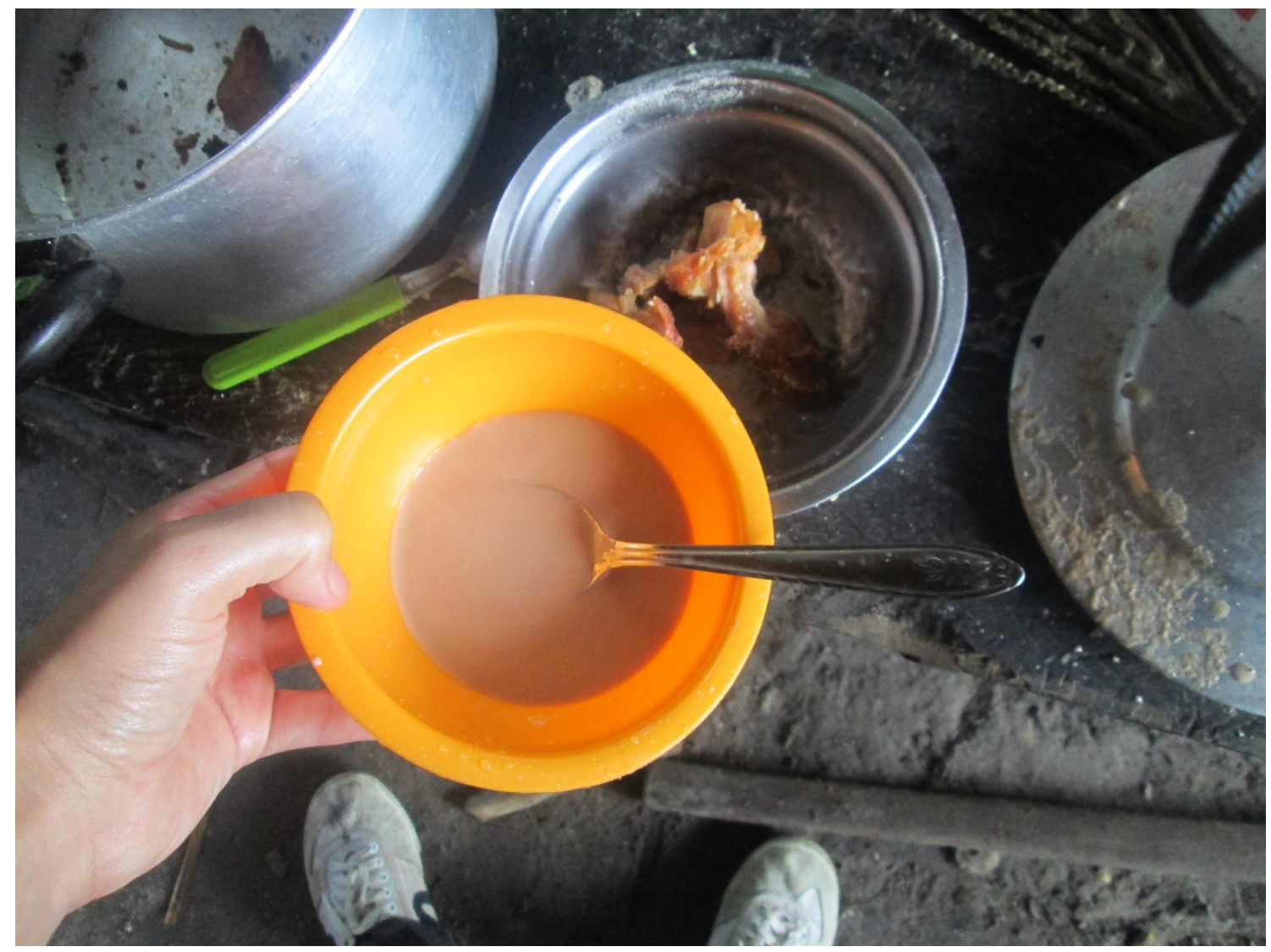

Convidados de fora da comunidade também são bem-vindos...

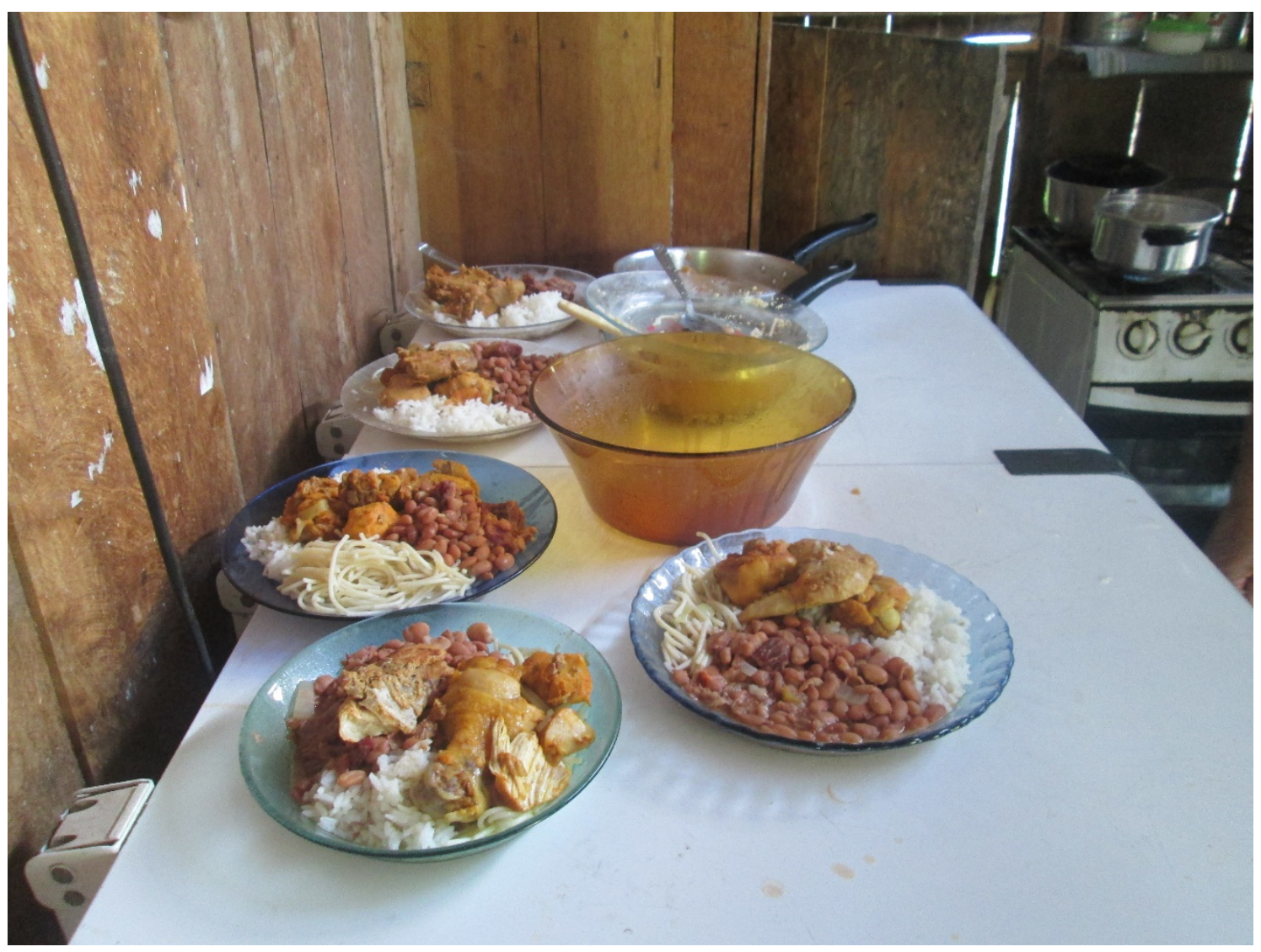

Iluminuras, Porto Alegre, v. 21, n. 54, p. 871-889, setembro, 2020. 
Convidados merecem um banquete...

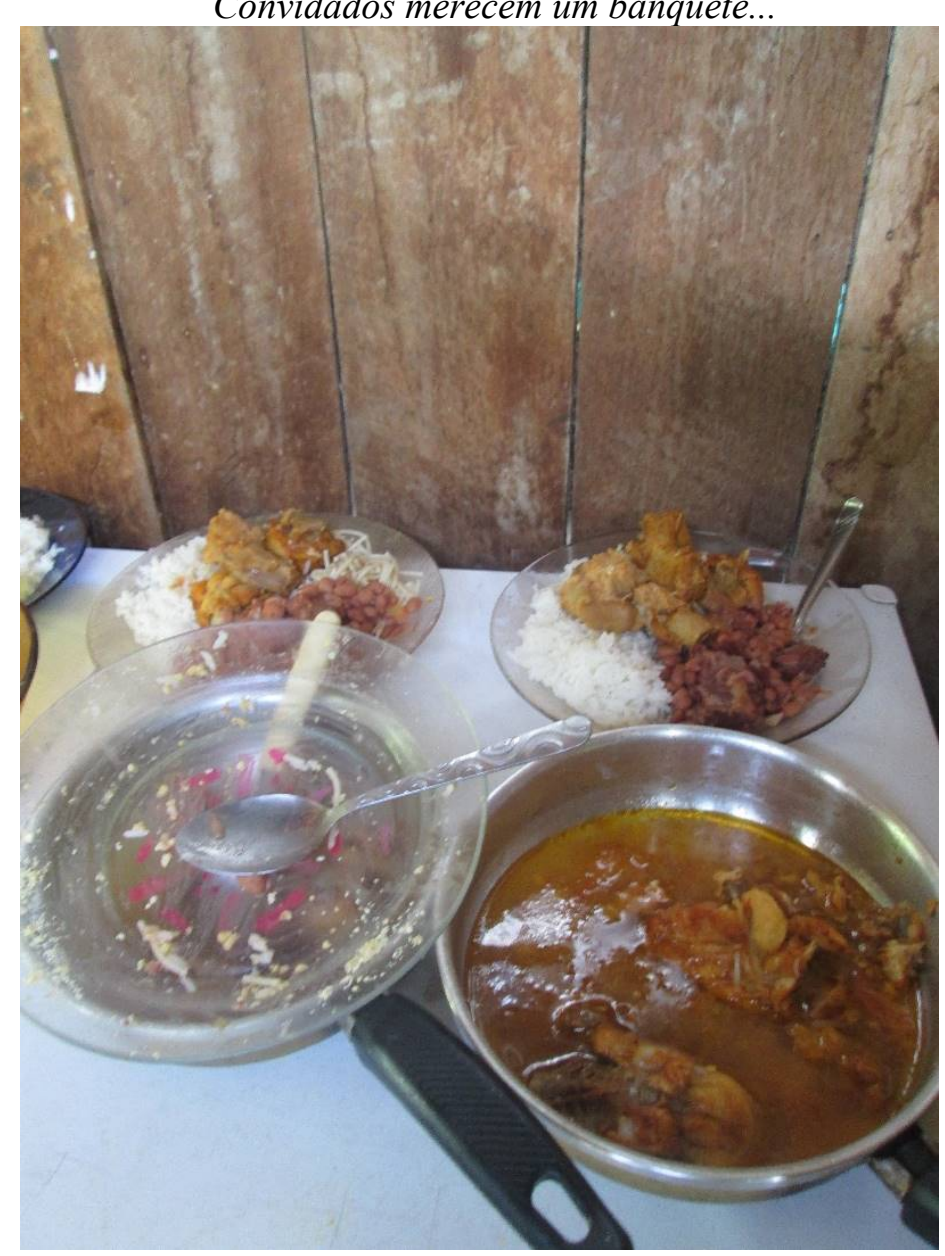

Convidados chegam com muita fome...

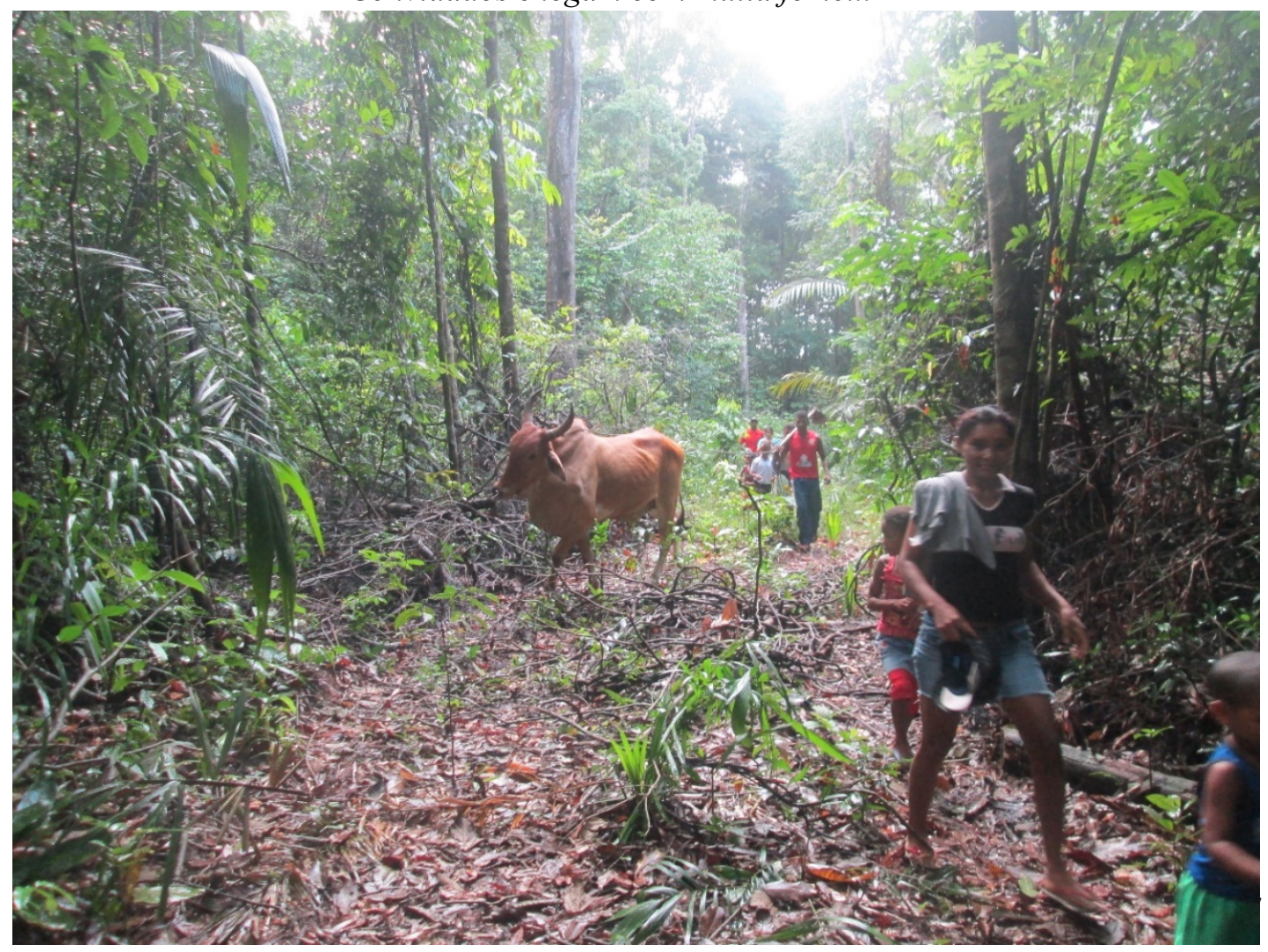

Iluminuras, Porto Alegre, v. 21, n. 54, p. 871-889, setembro, 2020. 


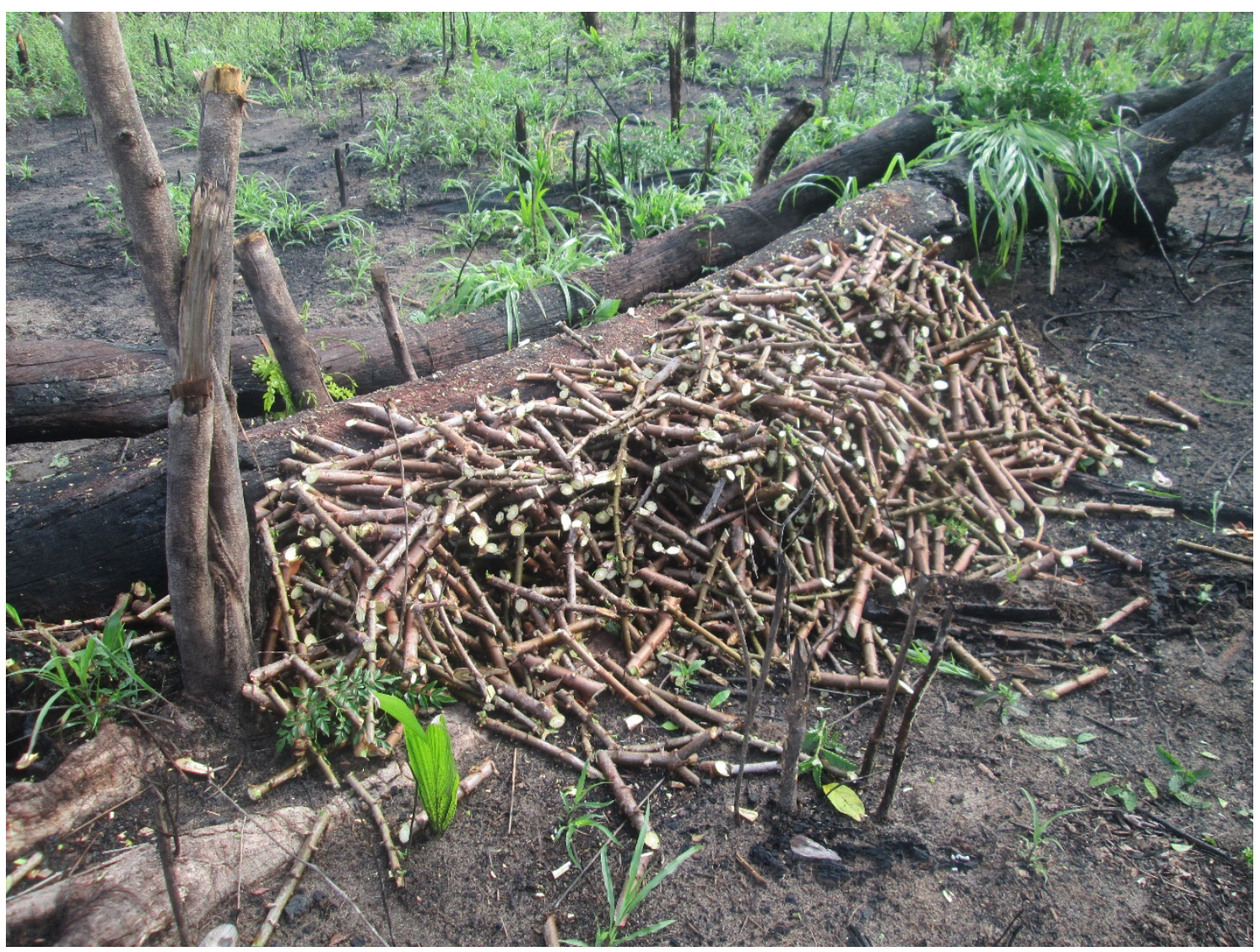

Reciprocidade no fazer-cortar...

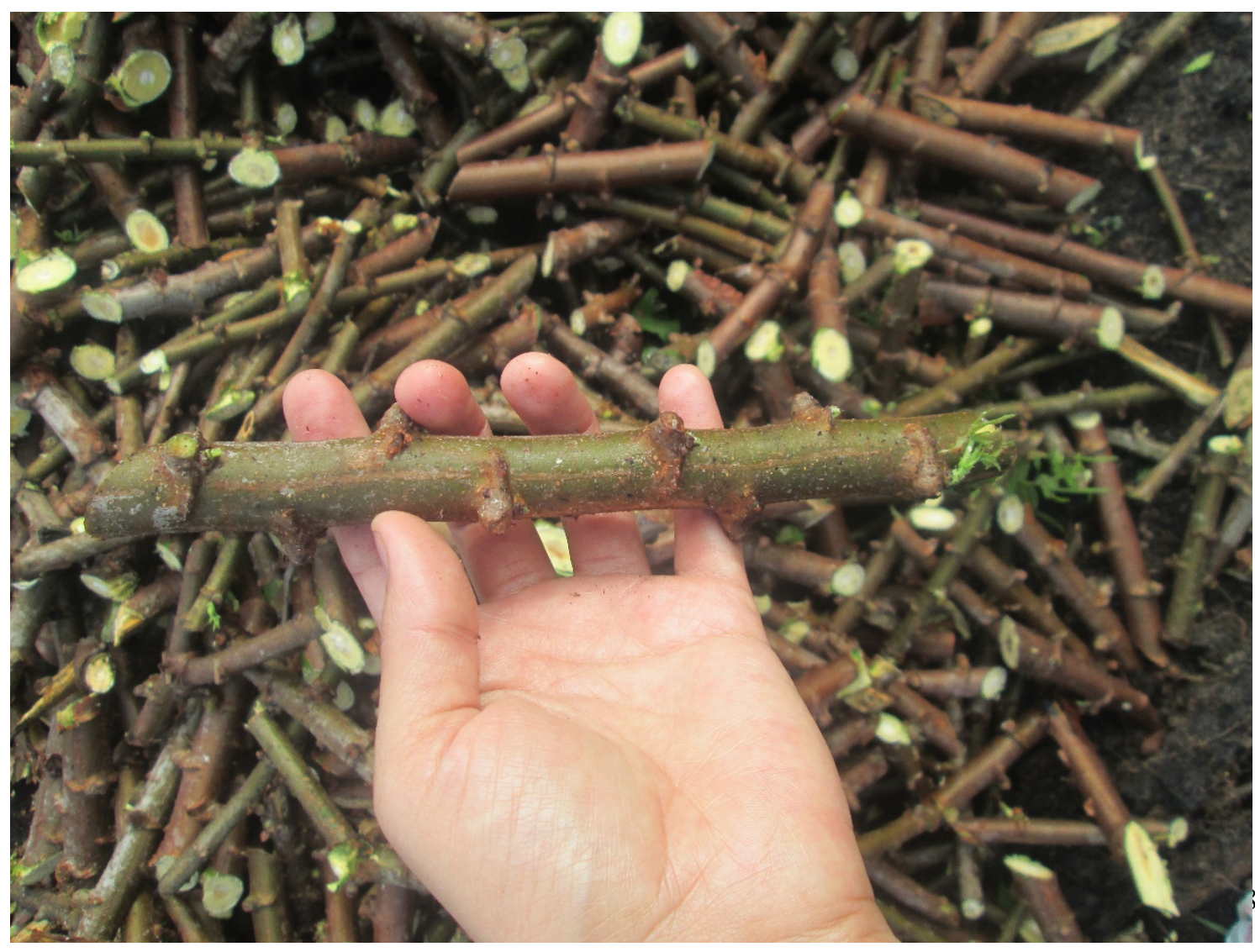

Iluminuras, Porto Alegre, v. 21, n. 54, p. 871-889, setembro, 2020. 


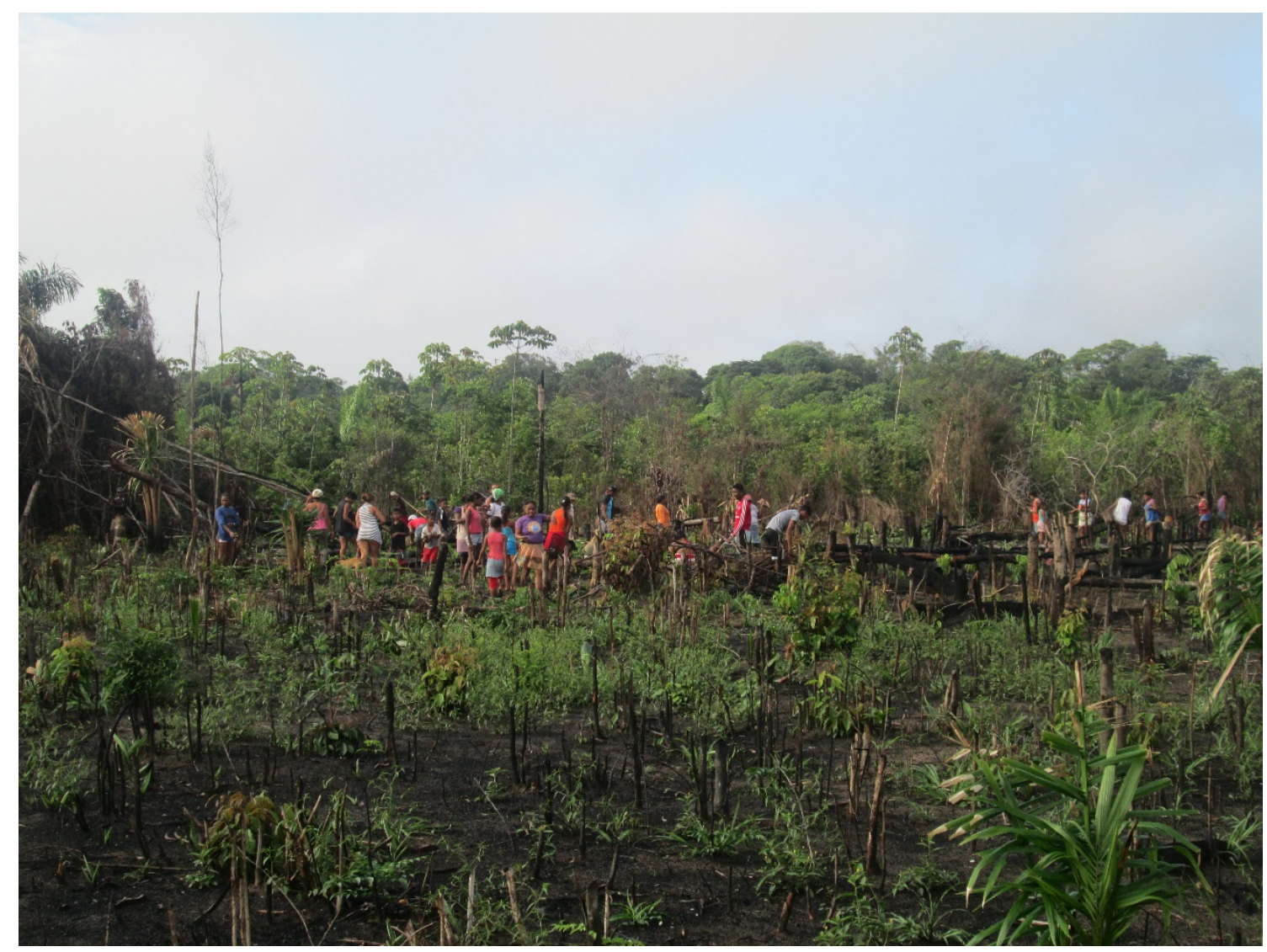

Reciprocidade no trabalho coletivo...

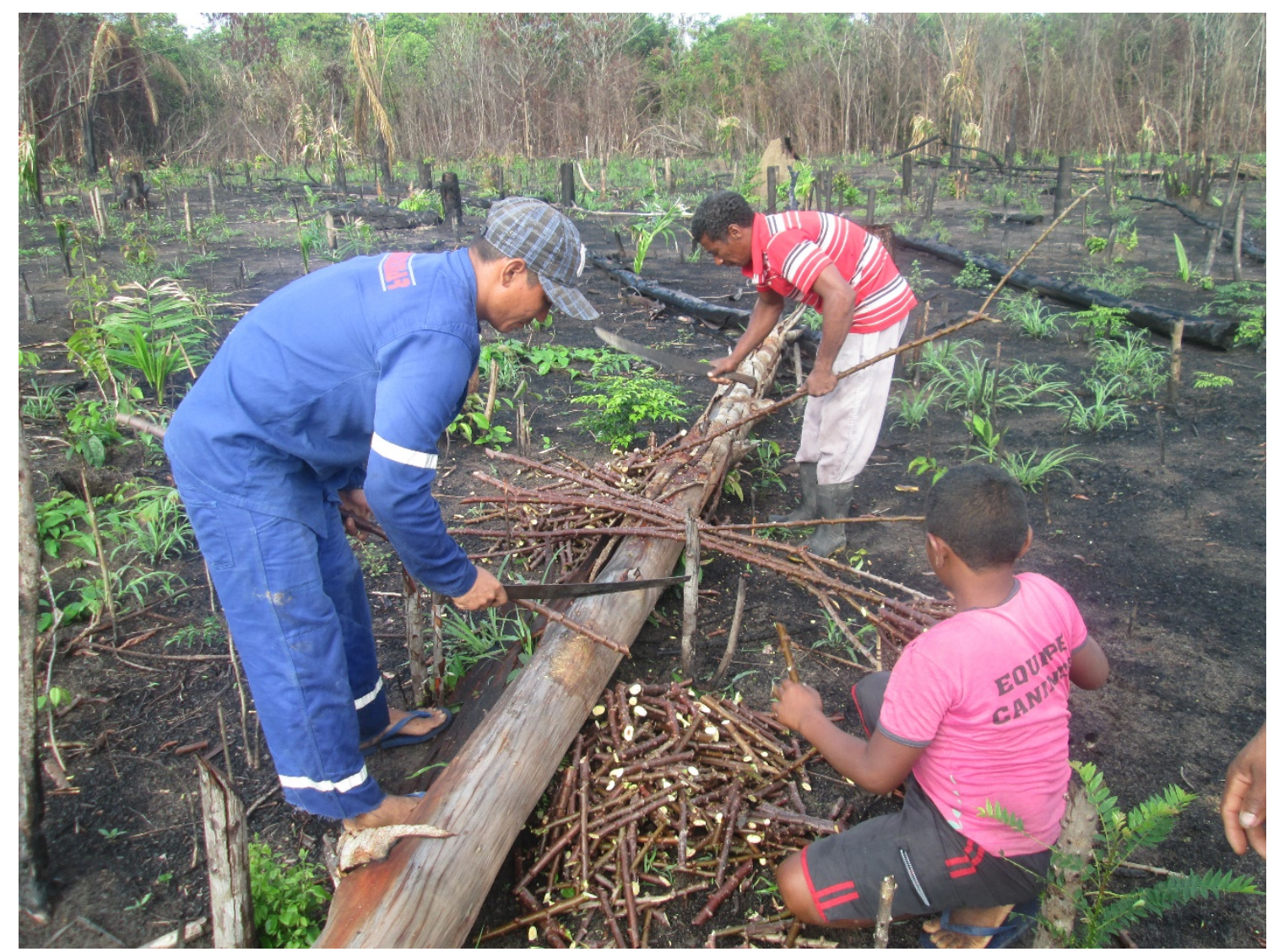

Iluminuras, Porto Alegre, v. 21, n. 54, p. 871-889, setembro, 2020. 


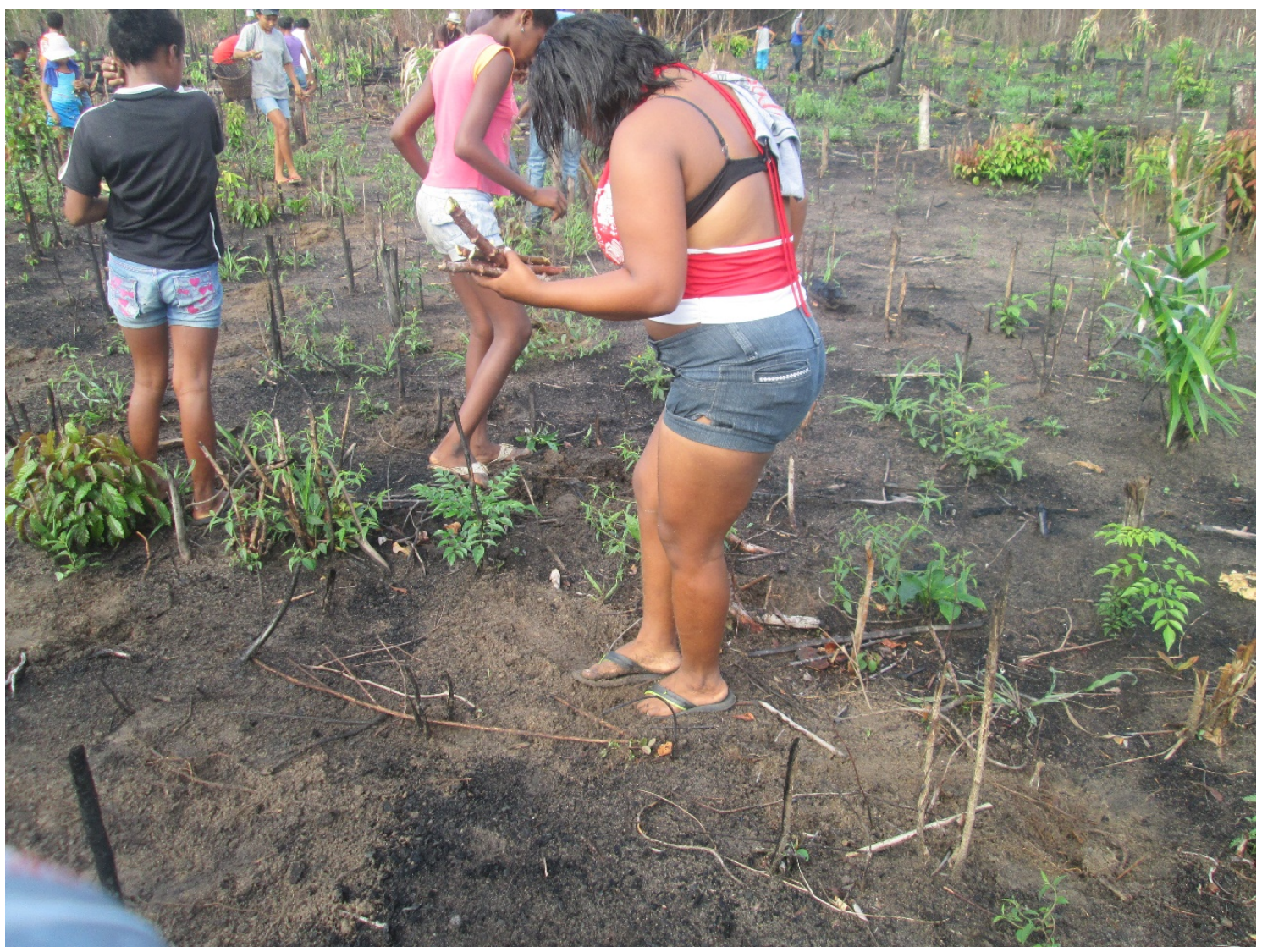

Aprendizado intergeracional...

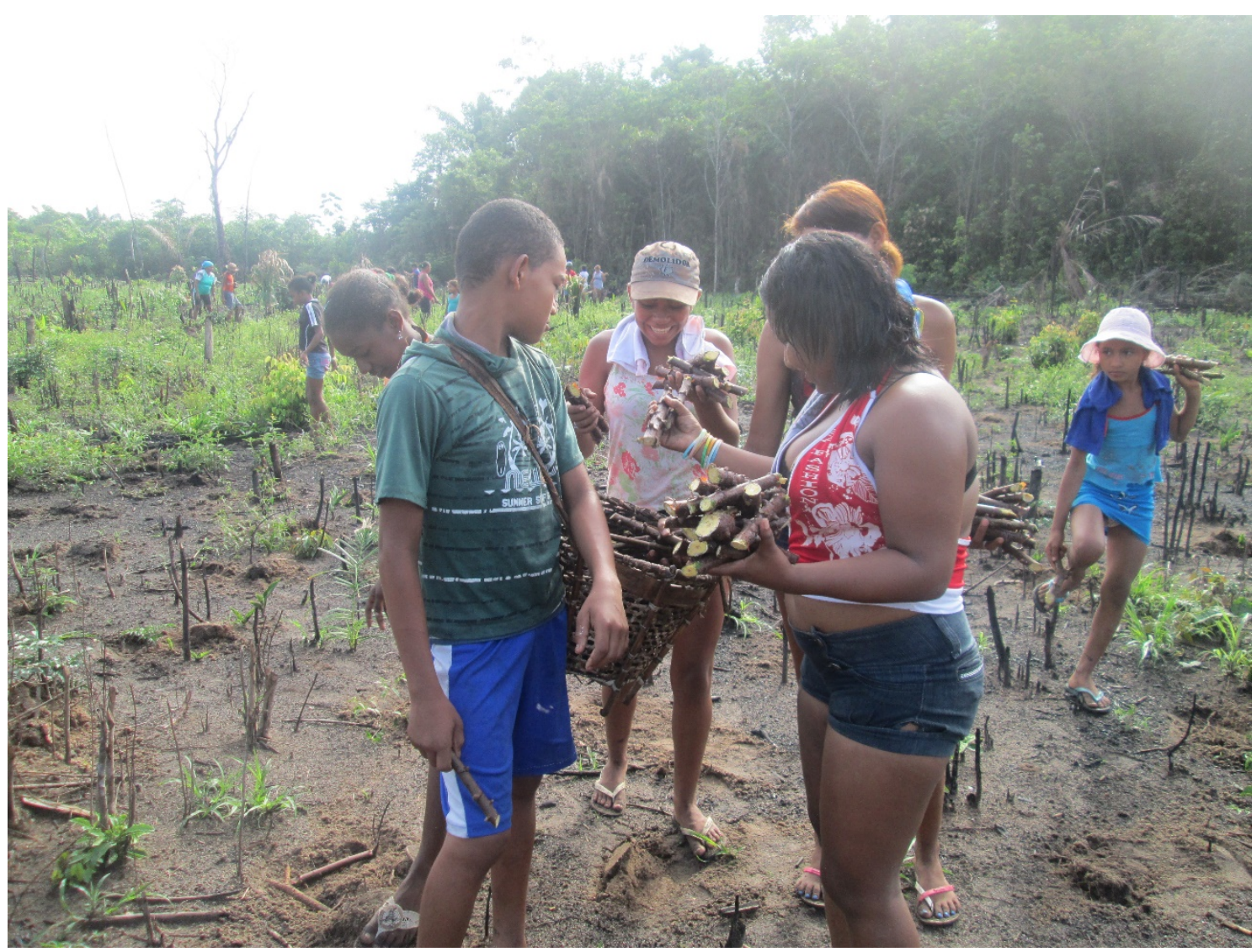

Iluminuras, Porto Alegre, v. 21, n. 54, p. 871-889, setembro, 2020. 


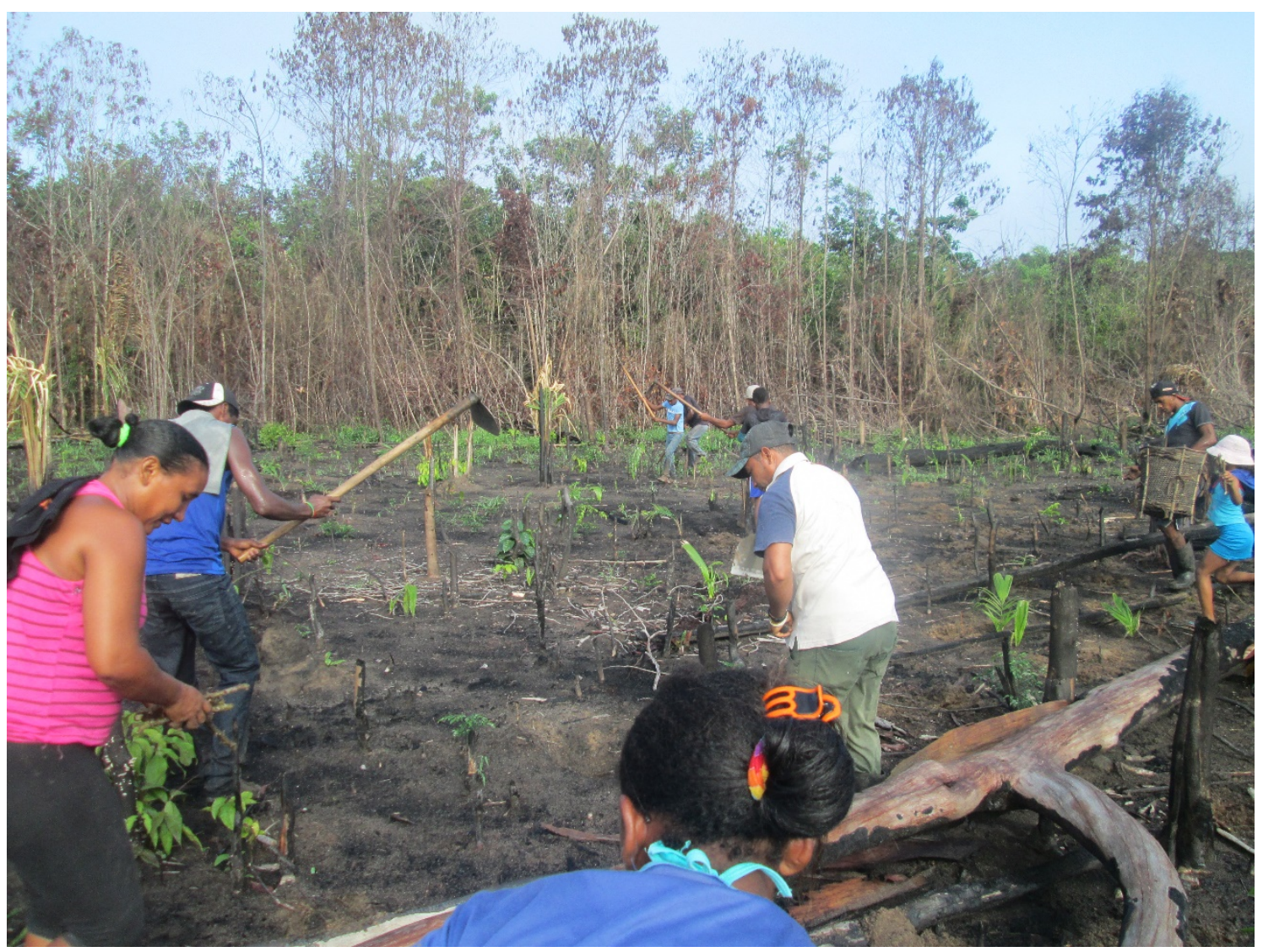

Interação entre homens mulheres, jovens...

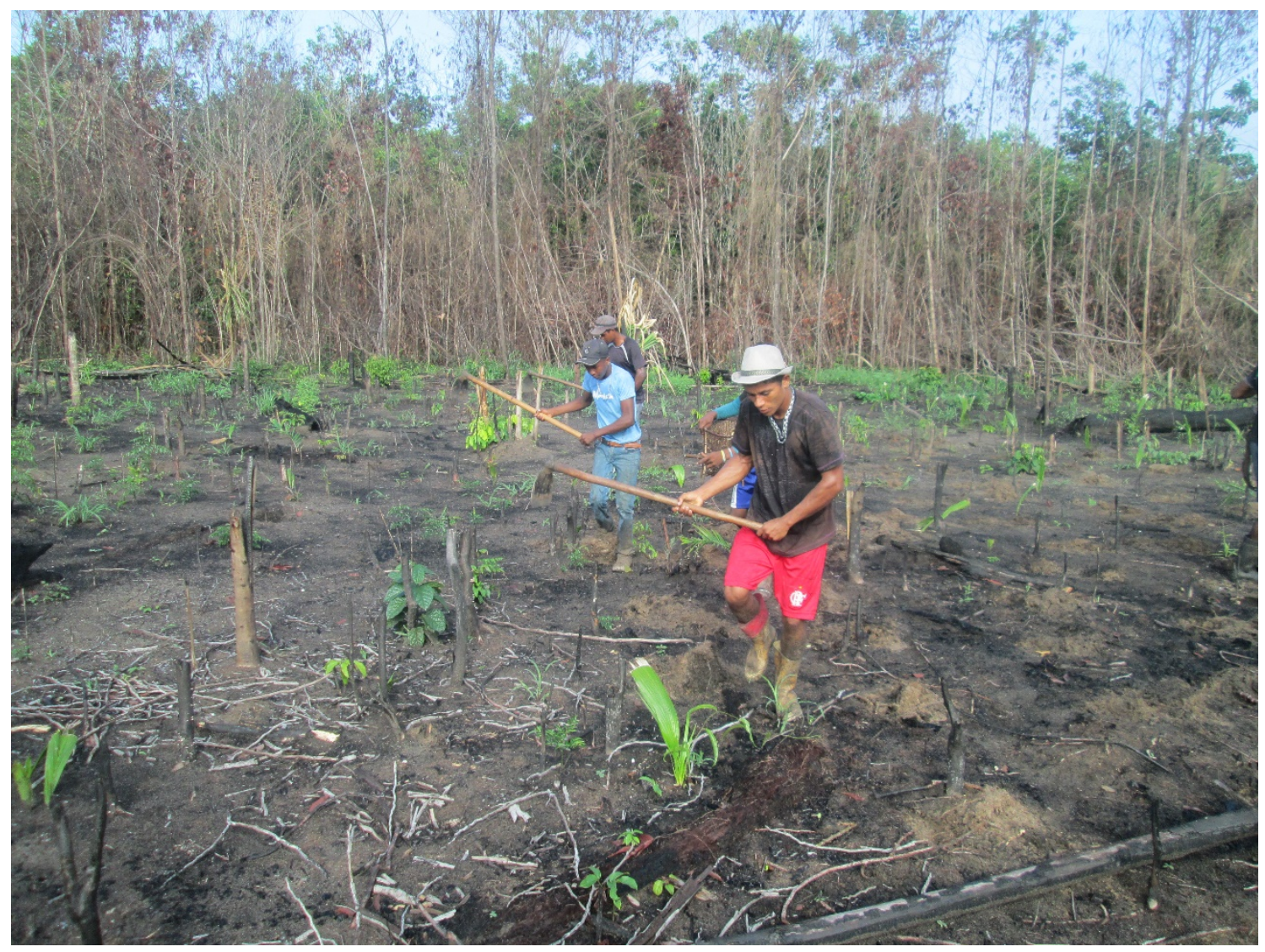

881

Iluminuras, Porto Alegre, v. 21, n. 54, p. 871-889, setembro, 2020. 


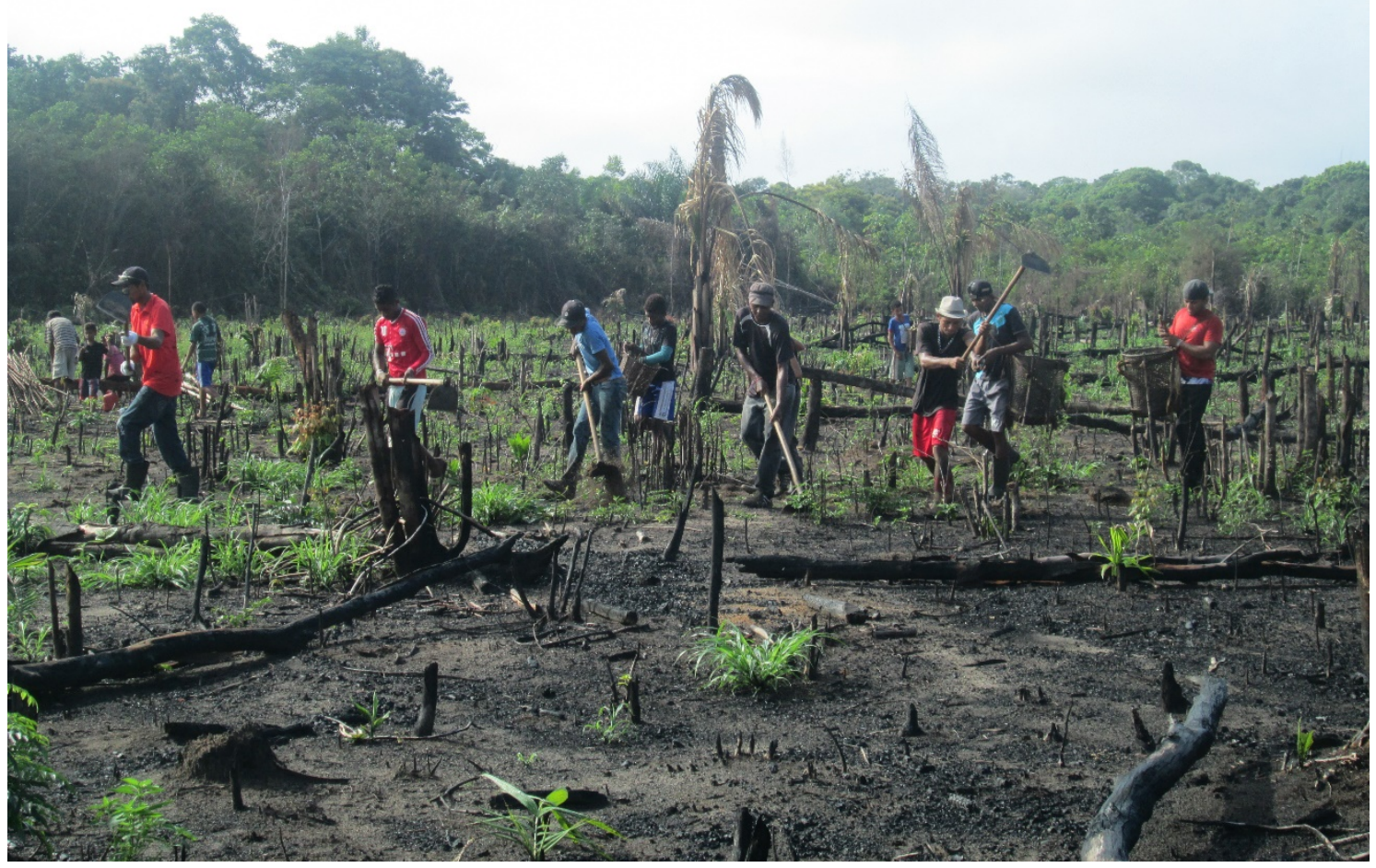

Muito trabalho...

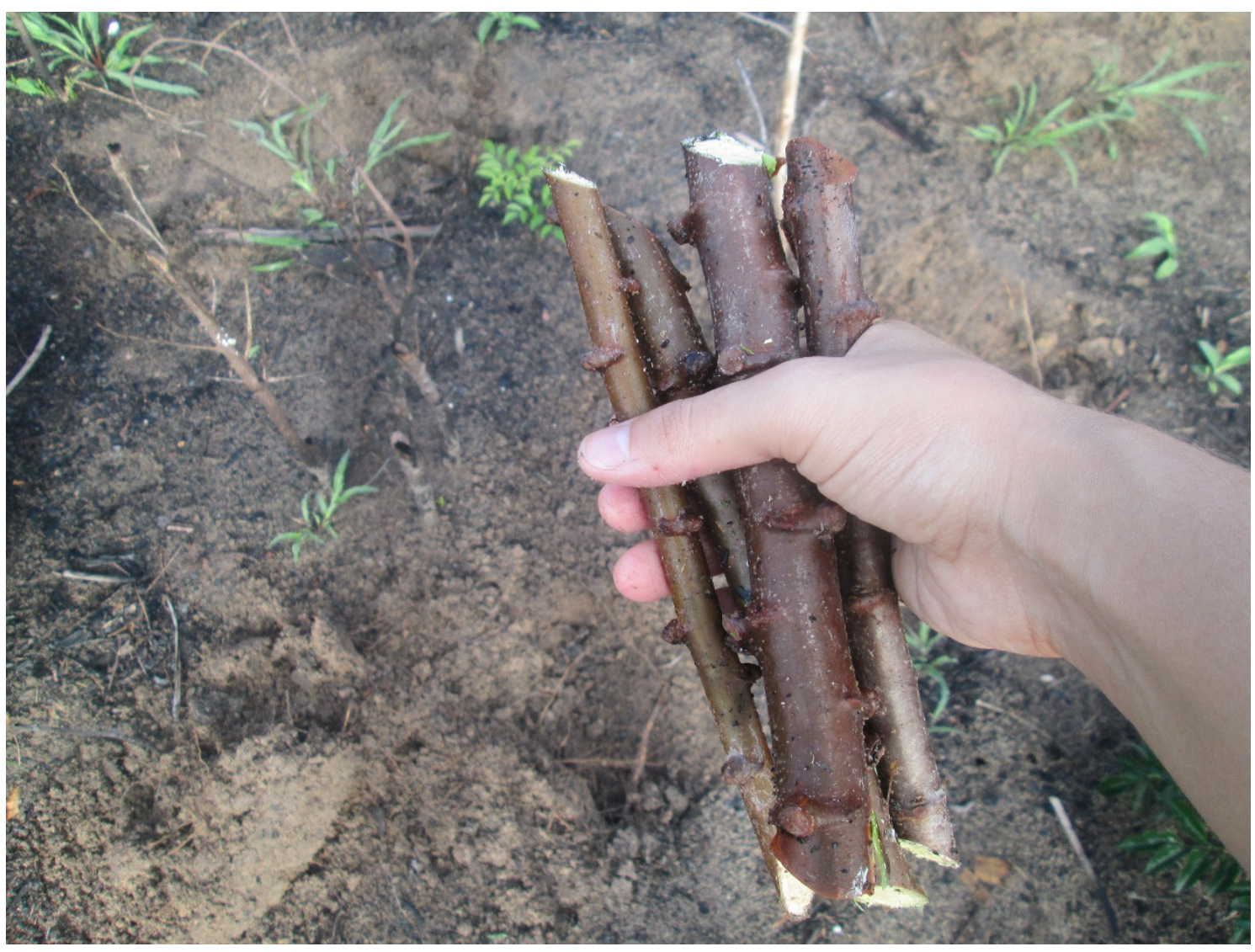

Iluminuras, Porto Alegre, v. 21, n. 54, p. 871-889, setembro, 2020. 


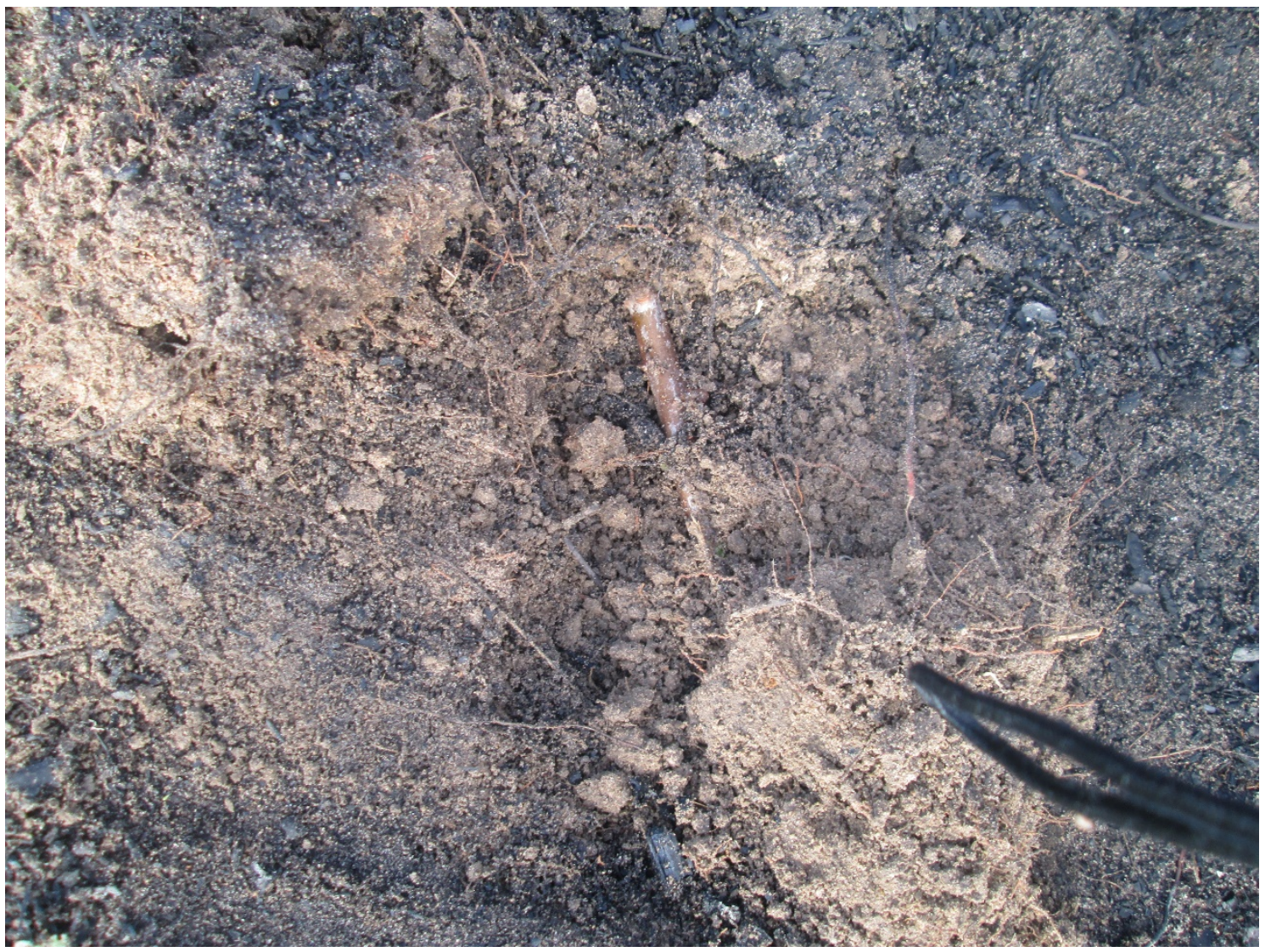

Acolhimento do saber tradicional...

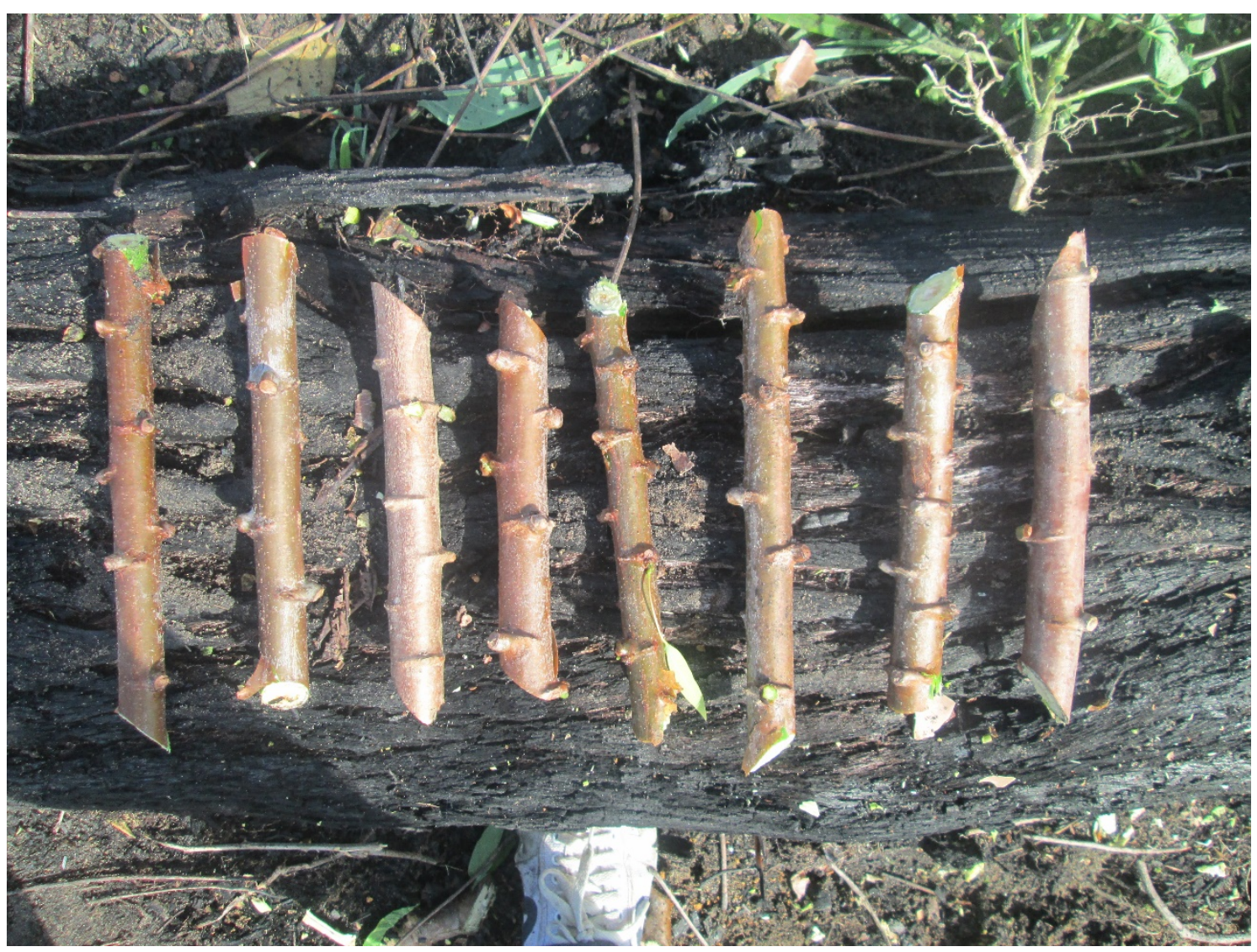

Iluminuras, Porto Alegre, v. 21, n. 54, p. 871-889, setembro, 2020. 


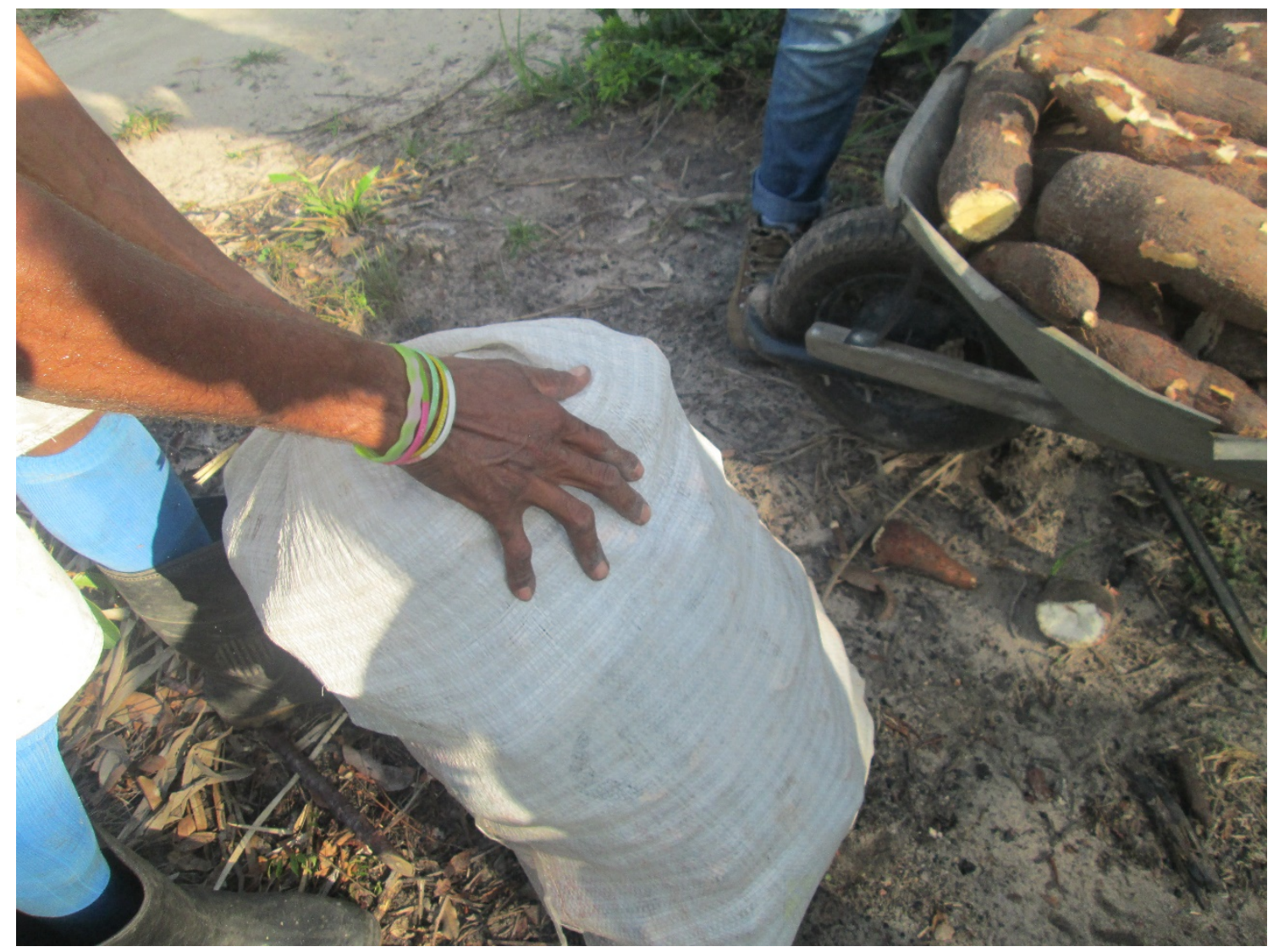

O fazer-farinha é também... inovação tecnológica e cultura...

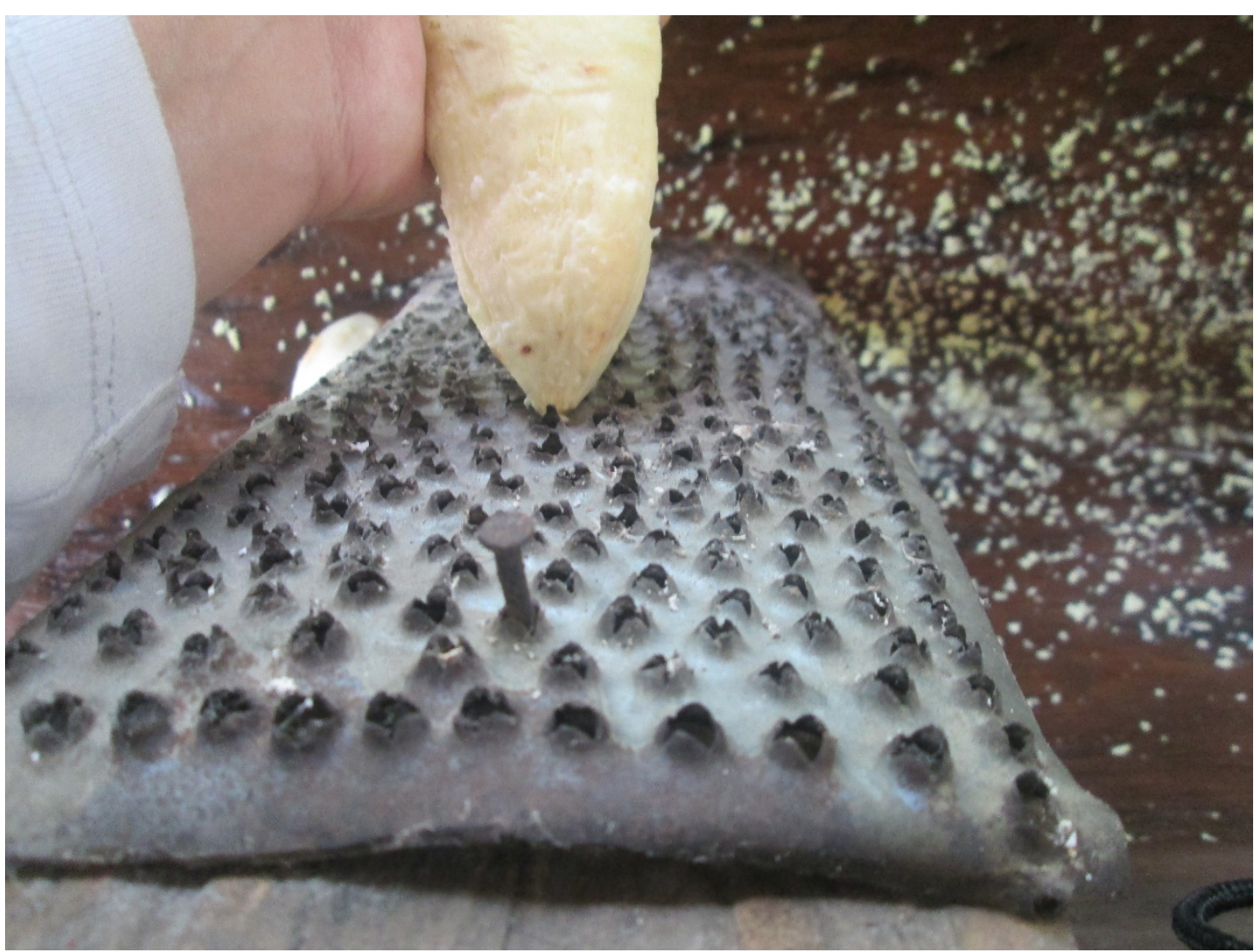

Iluminuras, Porto Alegre, v. 21, n. 54, p. 871-889, setembro, 2020. 


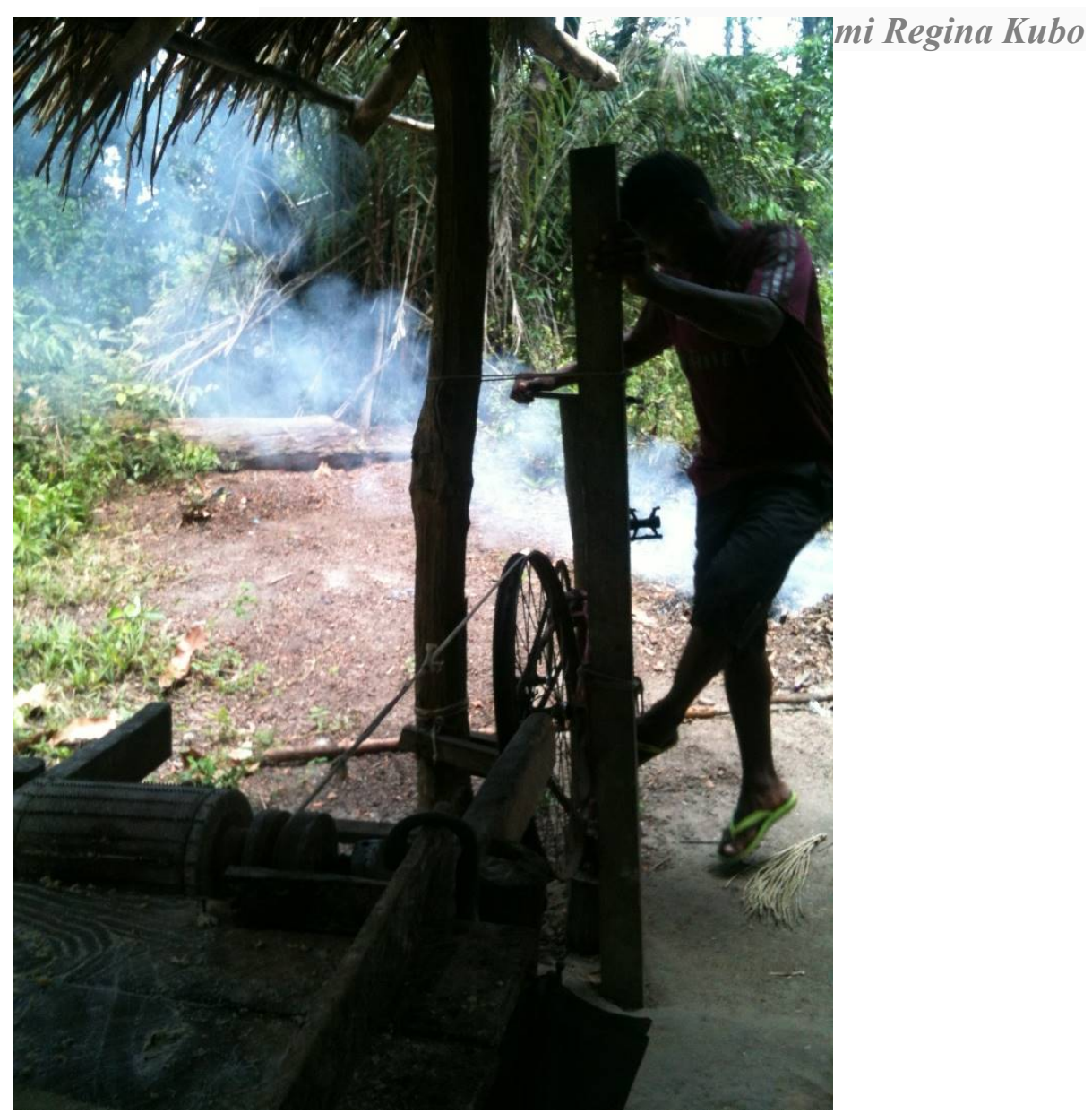

Inovação tecnológica é saber local...

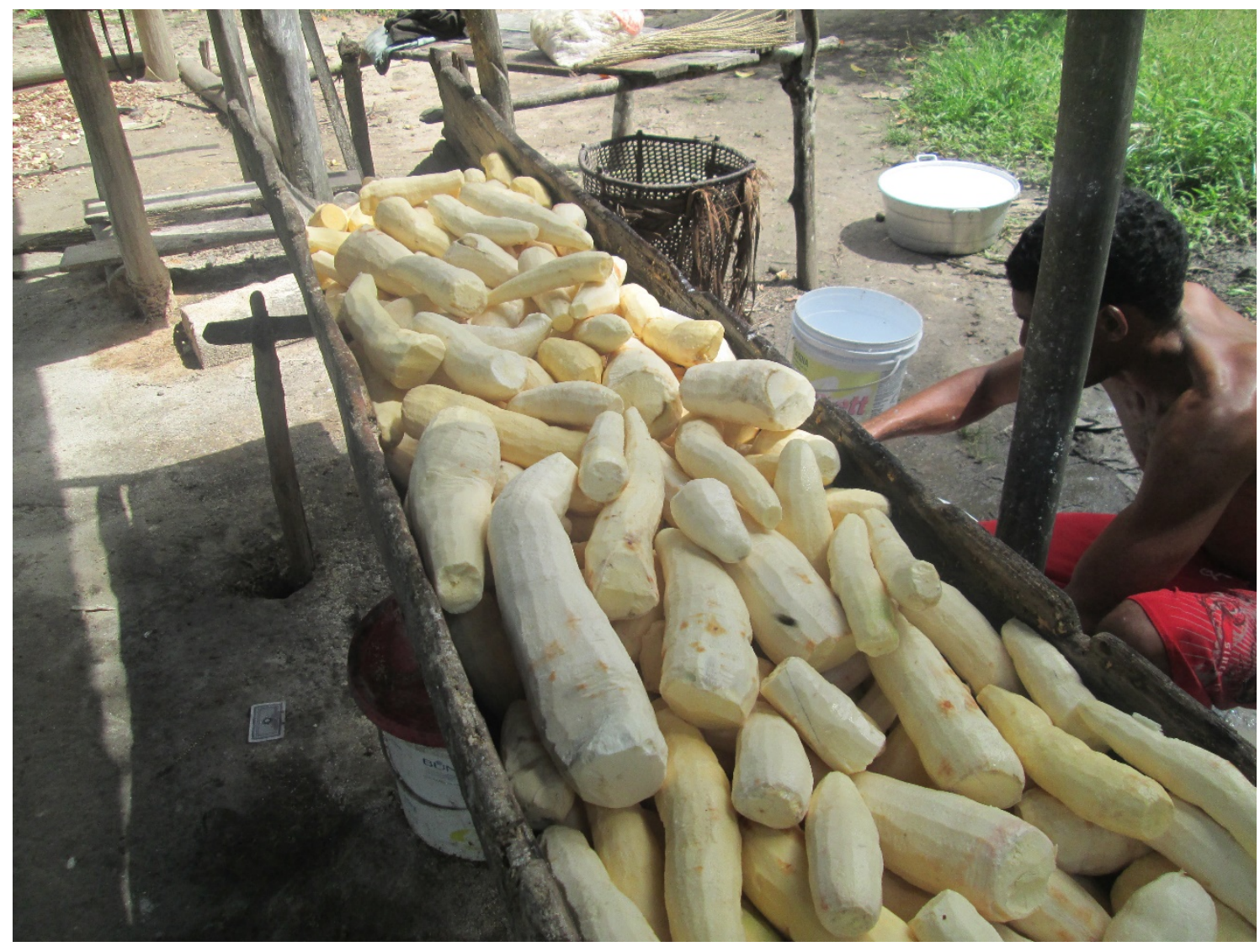

Iluminuras, Porto Alegre, v. 21, n. 54, p. 871-889, setembro, 2020. 


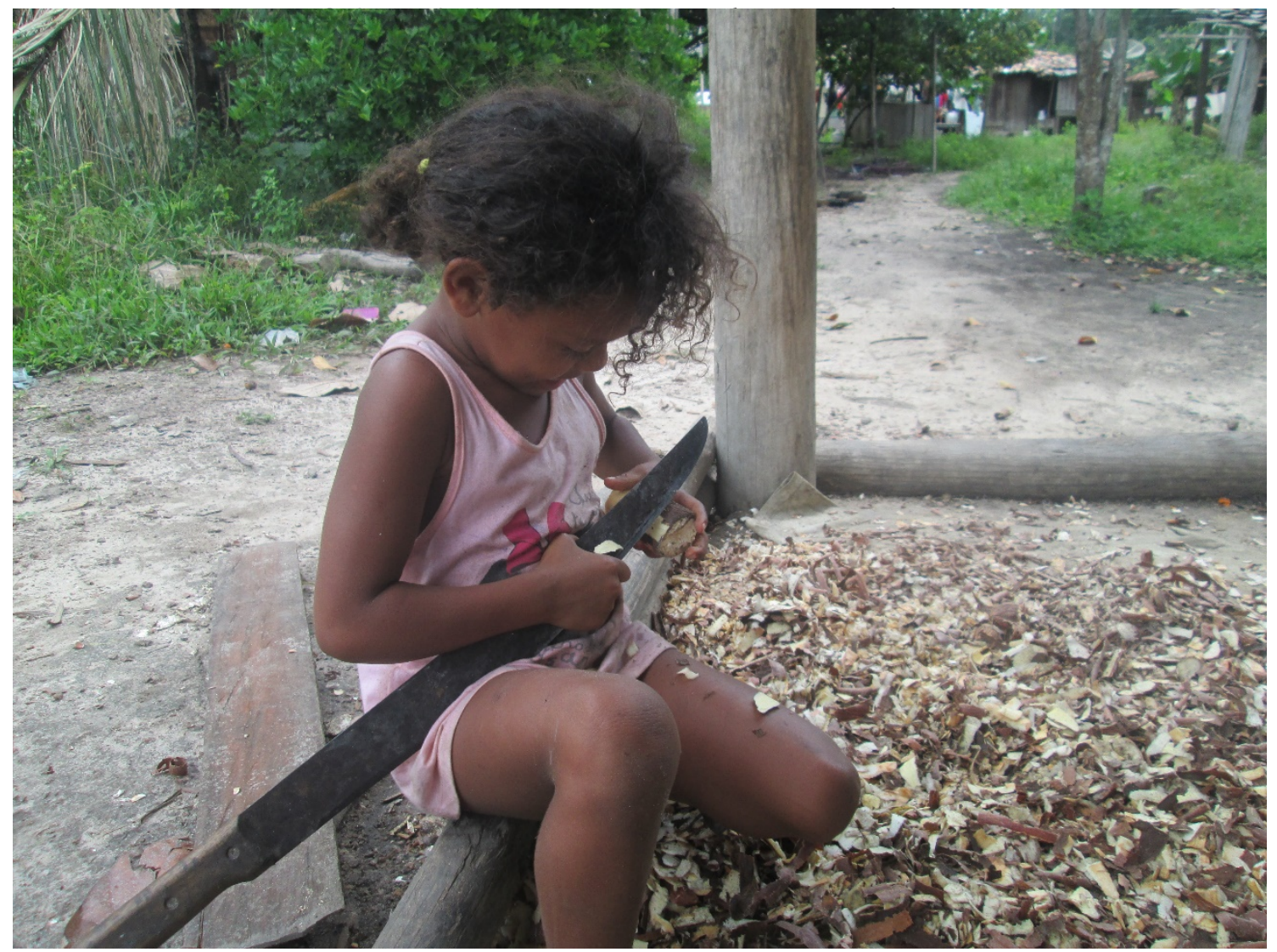

Cultura é transmissibilidade...

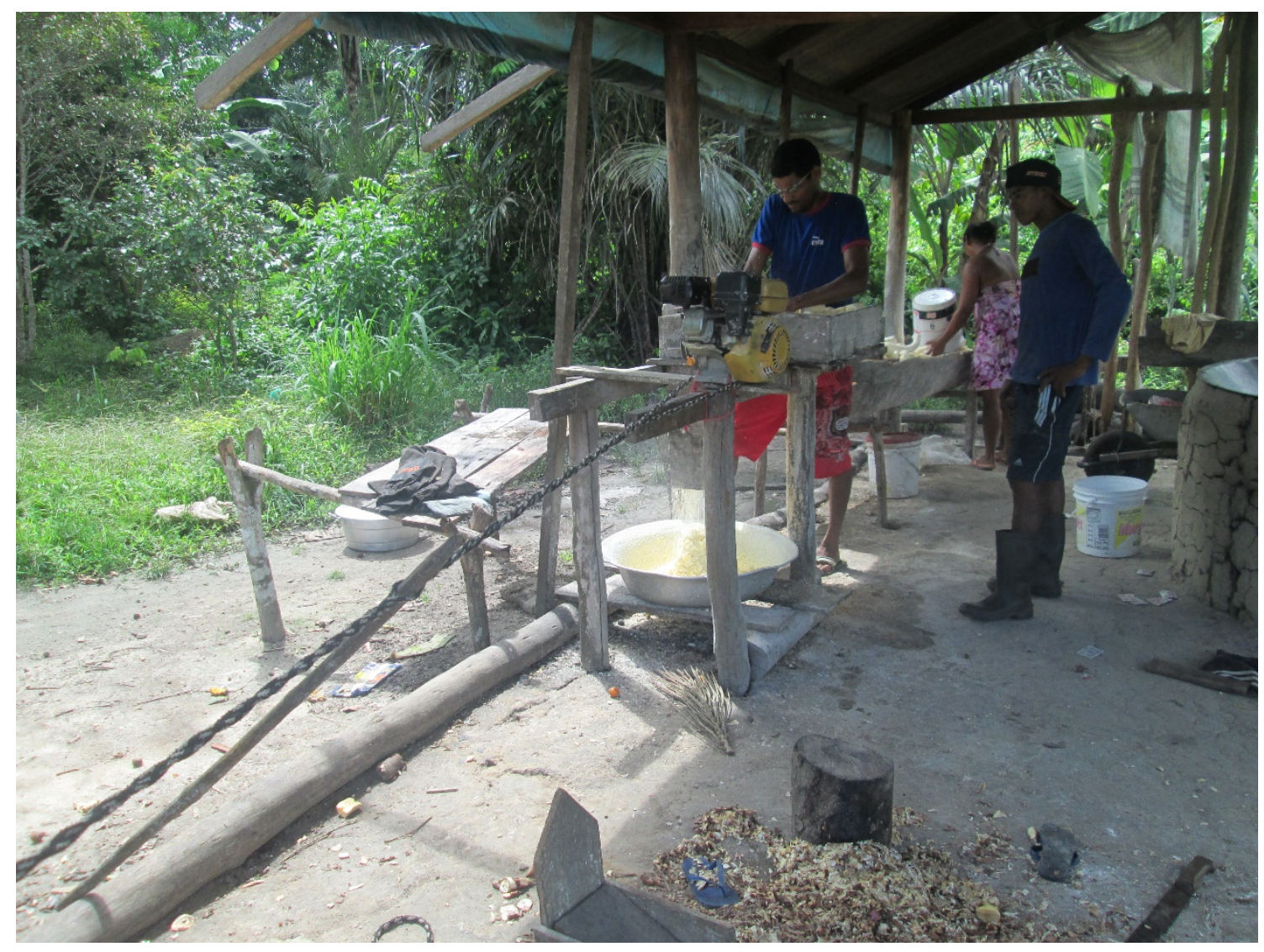

Iluminuras, Porto Alegre, v. 21, n. 54, p. 871-889, setembro, 2020. 


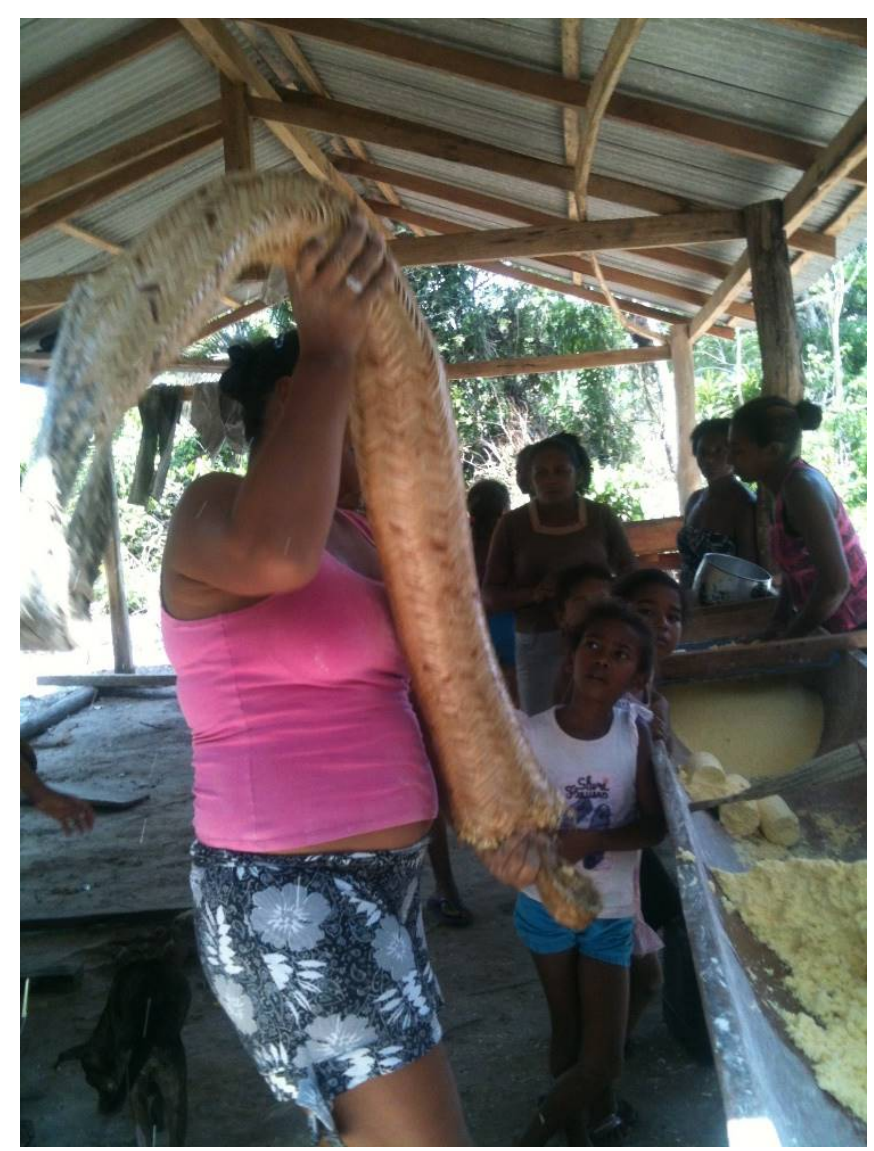

Cultura é conhecimento...

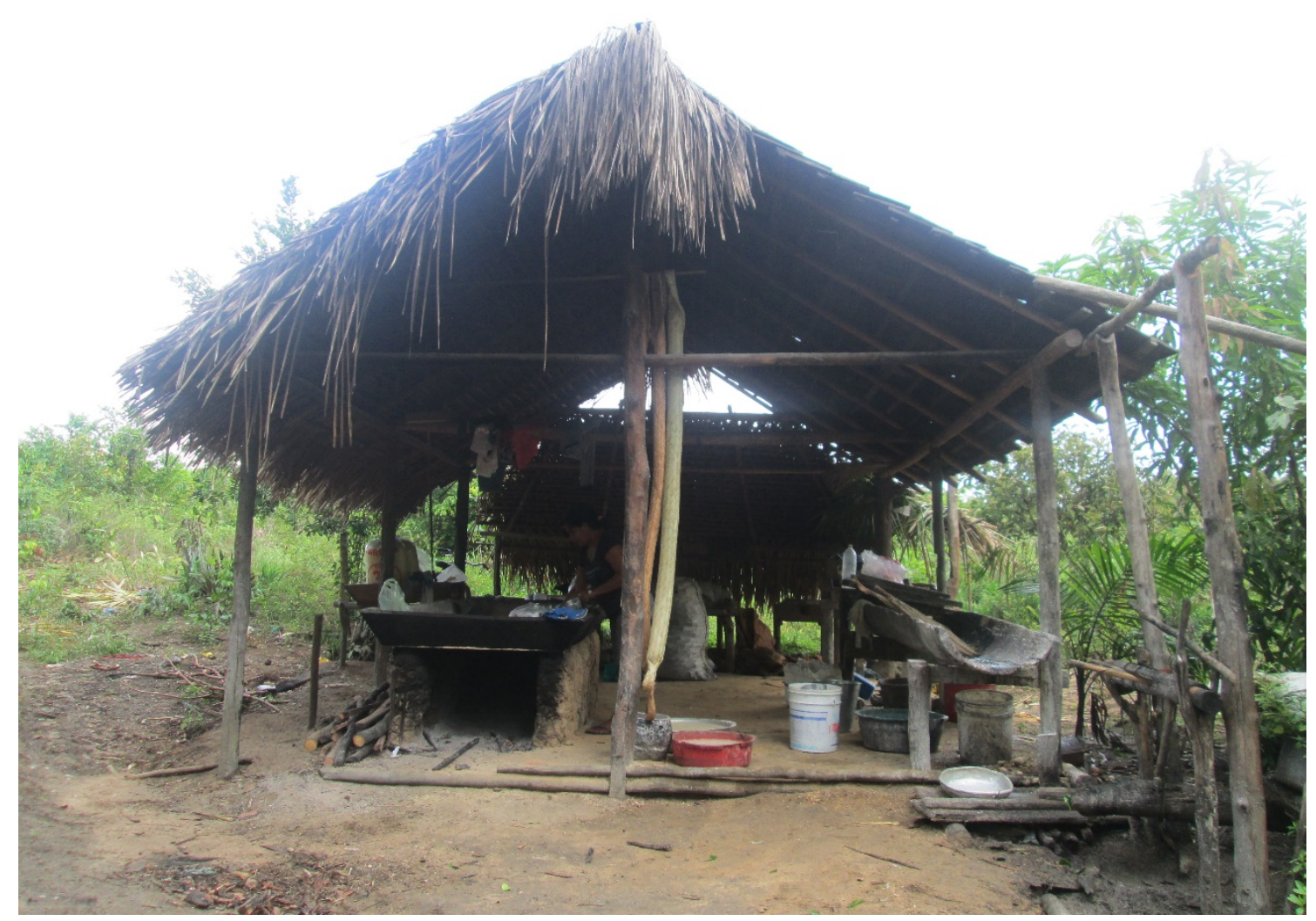

Iluminuras, Porto Alegre, v. 21, n. 54, p. 871-889, setembro, 2020. 


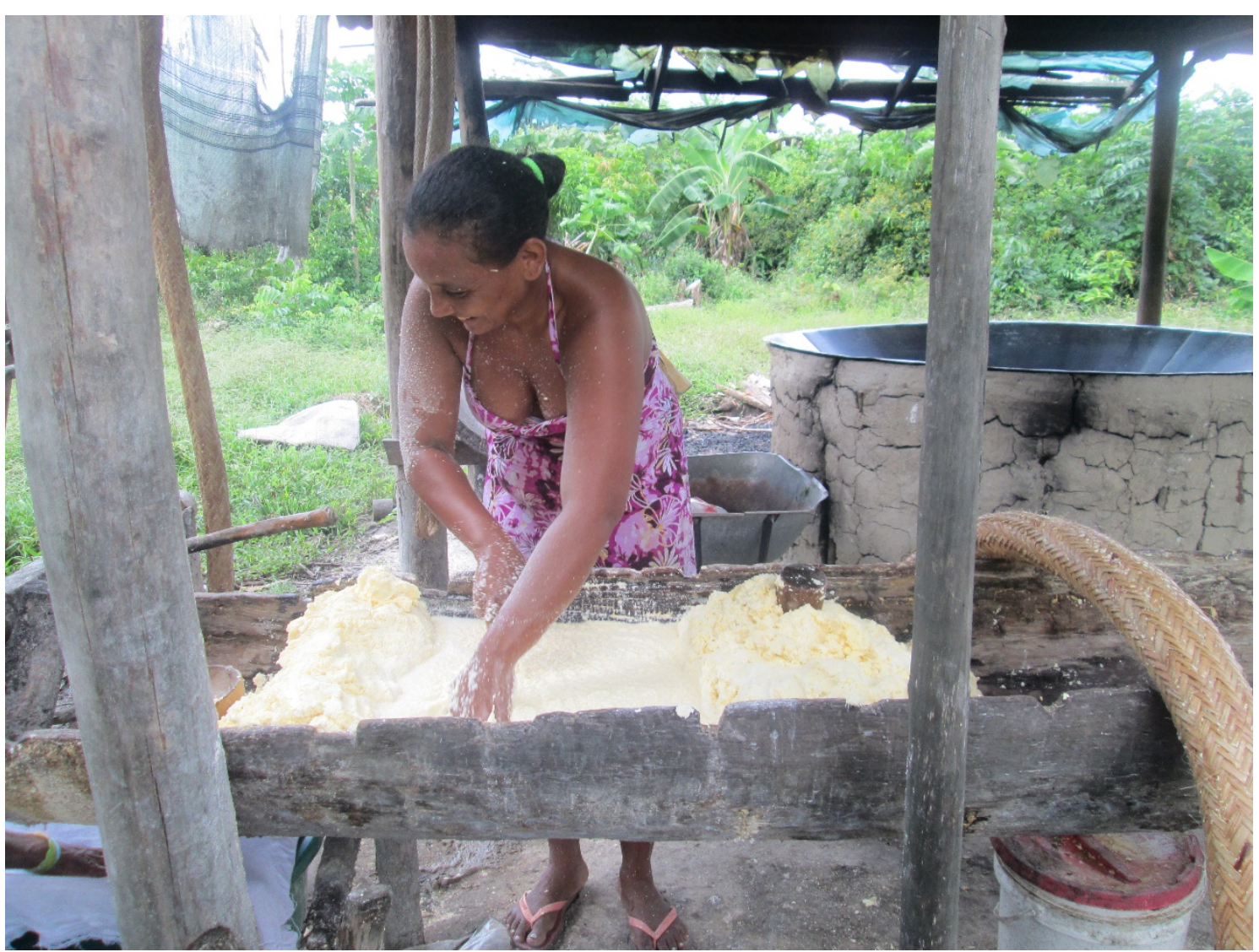

O fazer-farinha tem seus fazeres e saberes

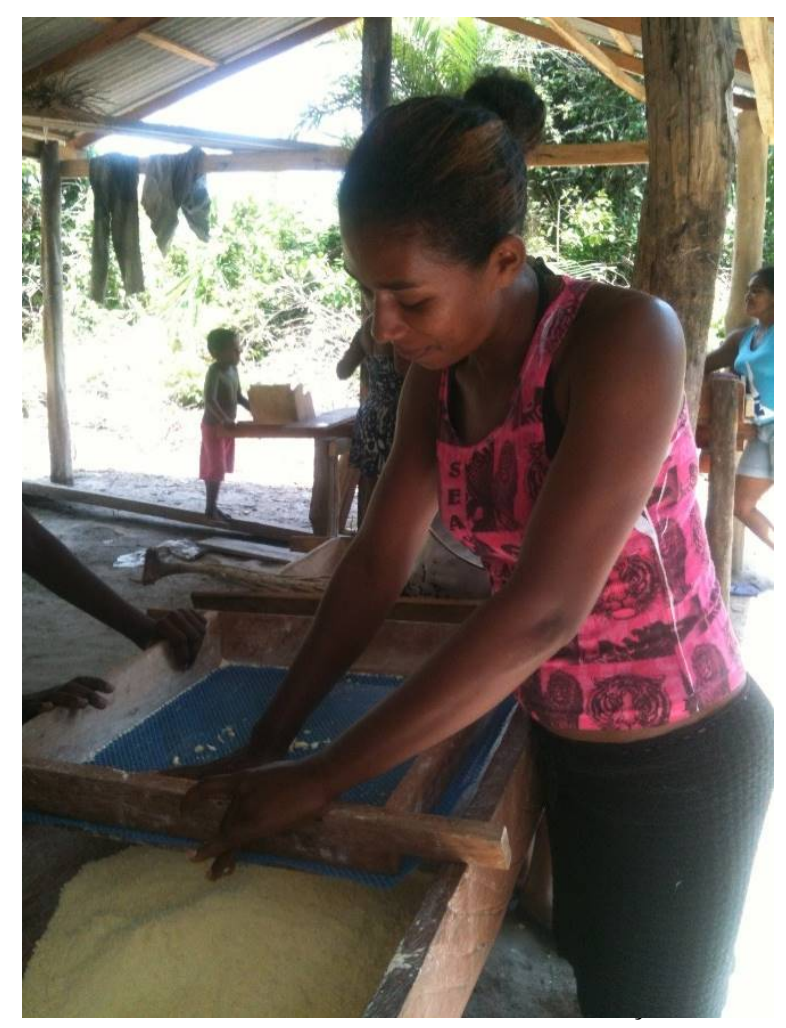

Iluminuras, Porto Alegre, v. 21, n. 54, p. 871-889, setembro, 2020. 


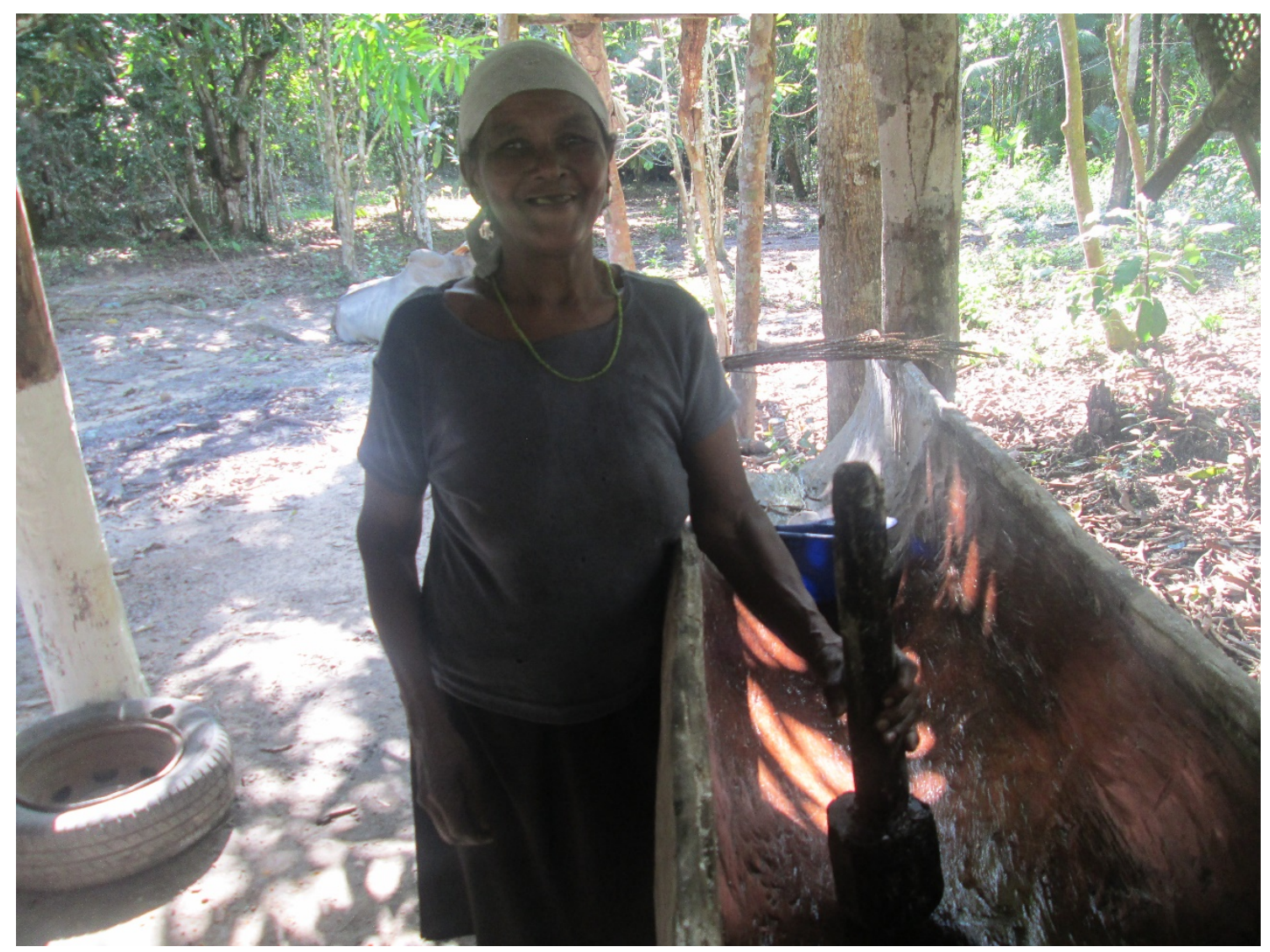

O fazer-farinha traz muita alegria e orgulho...

Recebido: $12 / 05 / 2020$

Aprovado: 04/09/2020 